\title{
Calcareous nannofossil age constraints on Miocene flysch sedimentation in the Outer Dinarides (Slovenia, Croatia, Bosnia-Herzegovina and Montenegro)
}

\author{
TAMÁS MIKES ${ }^{1}$, MÁRIA BÁLDI-BEKE², MIKLÓS KÁZMÉR, \\ ISTVÁN DUNKL ${ }^{1} \&$ HILMAR VON EYNATTEN ${ }^{1}$ \\ ${ }^{1}$ Sedimentologie/Umweltgeologie, Geowissenschaftliches Zentrum der Universität \\ Göttingen, Goldschmidtstrasse 3, D-37077 Göttingen, Germany \\ (e-mail:tamas.mikes@geo.uni-goettingen.de) \\ ${ }^{2}$ Rákóczi utca 42, H-2096 Üröm, Hungary \\ ${ }^{3}$ Department of Palaeontology, Eötvös University, Pázmány Péter sétány \\ 1/c, H-1117 Budapest, Hungary
}

\begin{abstract}
Flysch deposits are associated with the Outer Dinaride nappe front. They overlie Eocene platform carbonate to bathyal marl successions that subsequently cover Cretaceous platform carbonates of Apulia and the Dinaride nappes. Planktonic foraminifer biostratigraphy indicates Eocene age of flysch sedimentation. New calcareous nannofossil data reveal that several assemblages are present; besides the dominant Mid-Eocene species, Cretaceous, Paleocene, Oligocene and Miocene taxa were also identified throughout the entire flysch belt. Widespread occurrence of nannofossil species of zone NN4-6 indicates that flysch deposition lasted up to at least the Mid-Miocene. Ubiquitous occurrence of various pre-Miocene taxa demonstrates that extensive, possibly submarine, sediment recycling has occurred in the Cenozoic. As flysch remnants are typically sandwiched between thrust sheets, these new stratigraphic ages give a lower bracket on deformation age of the coastal range. The data provide a link between Cretaceous compression in the Bosnian Flysch and recent deformation in the Adriatic offshore area.
\end{abstract}

Cenozoic synorogenic clastic rocks overlie an upward-deepening Eocene carbonate platform to bathyal marl succession of the Apulian foreland and of the outermost parts of the SW-vergent Outer Dinaride thrust belt (Fig. 1). Established mostly on the basis of planktonic foraminifera, and locally by calcareous nannofossils, the stratigraphic age of the deposits has been traditionally placed into the Mid- or Late Eocene (Table 1). A SE-directed orogen-parallel younging of Palaeogene sedimentation has been inferred by Piccoli \& Proto Decima (1969).

Recent calcareous nannofossil studies indicate, however, that at several locations in the central and SE part of the basin system clastic deposition lasted up to the Middle Miocene (review in de Capoa \& Radoičić 2002). In addition, tectonic slices of older flysch series dated or inferred to be of Late Cretaceous and Palaeogene age are found in the inner part of the Dinaride imbricate thrust belt occupying structurally higher positions.

These contradictory data pose a series of important questions that need to be addressed in detail:

(1) Can ages younger than Eocene be demonstrated in the NW parts of the coastal flysch zone, too?
(2) Why do the age data from planktonic foraminifera and calcareous nannofossil studies seem to mismatch?

(3) Where and when did flysch deposition start? Are the deposits in the main belt and those preserved in narrow thrust slices related?

(4) Does revised biostratigraphy support the idea of diachronic onset of deposition along the orogenic front?

(5) What is the bearing of such young stratigraphic ages on the understanding of the Outer Dinaride geodynamic evolution?

In the present paper, new results of a calcareous nannofossil study are reported, obtained from several flysch localities throughout the Outer Dinaride region. Areas of large-scale regional sampling included the Trieste-Koper and Pazin Basins on the Istrian Peninsula, the Northern Kvarner Islands (Krk and Rab), Pag Island, Šopot section near Benkovac in Northern Dalmatia, Central Dalmatia, Southern Dalmatia, Montenegro coast as well as the 'Dalmatian-Herzegovinian Zone' of southern Bosnia-Herzegovina and Montenegro inland (Fig. 1 and Appendix B). 


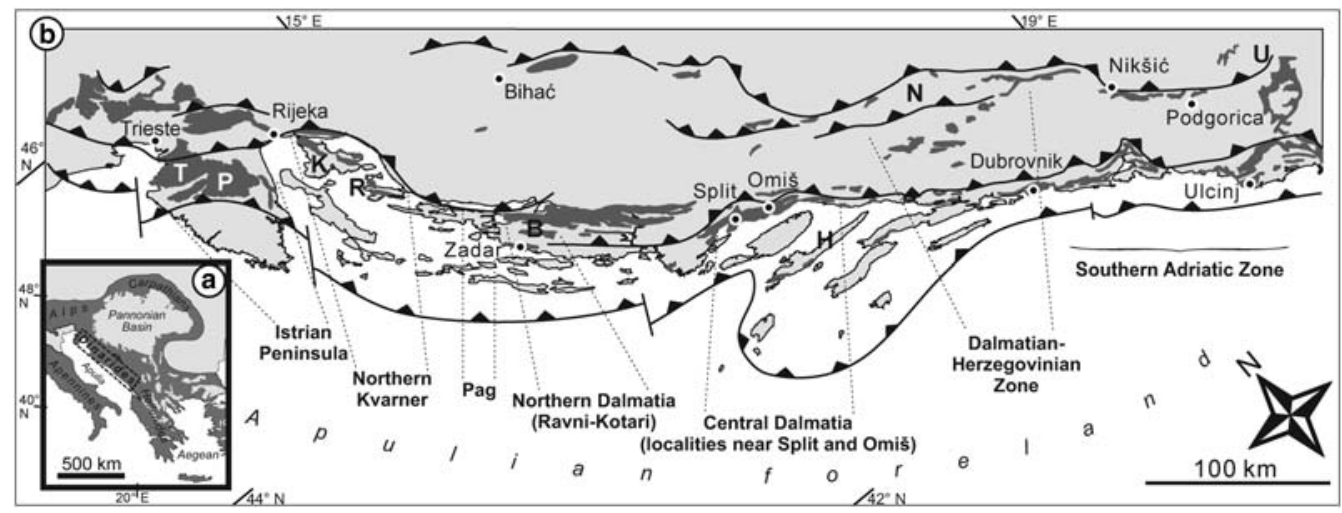

Fig. 1. (a) Position of the Dinarides within the European Alpine chain. Dark grey: Alpine orogen; light grey: post-orogenic basins. (b) Schematic geological setting of the Outer Dinarides with locations of the major sampling areas. Light grey: substrate of the flysch-mainly Palaeozoic to Mesozoic formations, dominantly platform carbonates. Dark grey: Cenozoic flysch and associated shallow marine sediments in the Outer Dinaride foreland basin system. T, Trieste-Koper Basin; P, Pazin Basin; K, Krk Island; R, Rab Island; B, Benkovac town; H, Hvar Island; U, Kuči Thrust; N, Nevesinjsko Polje. Position of thrusts after the Geological Map of Yugoslavia (F.G.I. 1970), Tari (2002) and Schmid et al. (2006).

\section{Geological setting and sedimentology}

The Outer Dinarides and their foreland are dominated by the thick deposits of the Adriatic Carbonate Platform (AdCP - Vlahović et al. 2005) that existed throughout the entire Mesozoic until its final drowning in the Mid-Eocene. Structurally, it consists of two parts: the lower plate corresponds to autochthonous Apulia, while the upper plate forms a broad, $c .100 \mathrm{~km}$ wide zone made up of the Dinaride nappes and imbricate thrust sheets. These units are built up mainly of Cretaceous rudistid limestones and Eocene foraminiferal limestones and marls, and are covered by Tertiary flysch that interfingers with and underlies shallow marine to continental clastic sediments. For extensive reviews of the Cenozoic stratigraphy, the reader is referred to Drobne (1977), Marjanac \& Ćosović (2000) and Ćosović et al. (in press). The carbonate nappes are thrust by the folded, Mesozoic units of the Bosnian Flysch and its low-grade metamorphic, Palaeozoic basement, the Bosnian Schist Mountains (BSM). They underwent Early Cretaceous metamorphism and the BSM was exhumed during the Eocene-Oligocene (Pamić et al. 2004; Petri 2007).

The Outer Dinaride flysch is part of the fill of a large foreland basin system at the front of the thrust wedges (Fig. 1). Sub-basins stretch from the southern Alps along the Adriatic Sea coastline as far to the SE as the Hellenides. Stratigraphic position of the flysch is described in terms of a Paleogene marine sequence overstepping the Cretaceous platform. The underlying foraminiferal ramp covers a regionally widespread unconformity and started to develop in the Paleocene with paralic deposits. Facies development indicates transgression throughout the Early to Middle Eocene but the sequence is punctuated with a number of short-lived subaerial exposure events probably due to the interplay of eustatic oscillations in a shallow marine environment and the effects of ongoing compressional tectonics affecting the Adriatic area already since the Cretaceous (Channell et al. 1979; Mindszenty et al. 1995; Pamić et al. 1998). The Eocene carbonate unit is rarely thicker than $200 \mathrm{~m}$ and is overlain by the 'Transitional Beds' - a deepening-upward shelf to shallow bathyal sequence several tens of metres thick, characterized by increasing amount of pelagic biota, glauconite and silt upsection. Its thin lower part is referred to as 'Marl with crabs', passing upwards into the thick 'Globigerina Marl' (e.g. Juračić 1979; Ćosović et al. 2004).

The flysch rests upon the 'Globigerina Marl'. Their contact is conformable at places but angular or erosional unconformities have often been reported (e.g. Marinčić 1981; Marjanac et al. 1998; Marjanac 2000). Due to repetitive thrusting, flysch profiles are usually truncated and less than 100-400 m thick. The offshore succession resting on the Apulian Plate is gently folded, reaches up to the Neogene, and may exceed $1000 \mathrm{~m}$ in thickness (e.g. Tari-Kovačić 1998).

Turbidite beds are dominantly composed of siliciclastics with variable $(0-50 \%)$ amounts of carbonate admixture. In the $\mathrm{N}$ part of the basin, palaeocurrent data were interpreted as resulting from largely SW-directed primary, and SE-directed 
Table 1. Overview of published age data from the Outer Dinaride flysch. Offshore and sporadic mainland data are not included. Whenever available, standard planktonic foraminifer or calcareous nannoplankton biozones are also indicated. Results yielding Neogene age are marked bold for clarity. Abbreviations: $n p$, nannofossils; pf, planktonic foraminifera; lf, larger foraminifera; po, palynomorphs; mo, mollusc macrofauna

\begin{tabular}{|c|c|c|c|c|c|c|}
\hline Area & Age & Locality & Source & Age based on & Biozone & Notes \\
\hline \multirow[t]{17}{*}{ Istria } & Upper Oligocene & Pićan & Šparica et al. (2005) & lf, $n p$, po & & \\
\hline & Priabonian & Oprtalj & Benić (1991) & $\mathrm{np}$ & NP18 & \\
\hline & $\begin{array}{l}\text { Upper Eocene/Lower } \\
\text { Oligocene }\end{array}$ & Pazin, Motovun & Marinčić (1981) & $\mathrm{pf}$ & & \\
\hline & Upper Eocene & Pićan & Drobne et al. (1979) & $\mathrm{pf}, \mathrm{np}$ & & 1 \\
\hline & $\begin{array}{l}\text { Middle Lutetian to Lower } \\
\text { Priabonian }\end{array}$ & several localities, review & Ćosović et al. (in press) & $\mathrm{pf}, \mathrm{np}$ & P11-P15 & \\
\hline & Bartonian & Pričejak (Učka) & Benić (1991) & $\mathrm{np}$ & NP17 & \\
\hline & Bartonian & Pićan & Benić (1991) & $\mathrm{np}$ & NP17 & \\
\hline & Upper Lutatian-Bartonian & Pićan & Hagn et al. (1979) & $\mathrm{np}$, lf, $\mathrm{pf}$ & NP16 & \\
\hline & Upper Middle Eocene & several localities & Krašeninnikov et al. (1968) & pf & & \\
\hline & Middle Eocene & Vranja, Velanov brijeg & Stradner (1962) & $\mathrm{np}$ & & 2 \\
\hline & Middle Lutetian & Pićan & Pavlovec et al. (1991) & pf, np & & 3 \\
\hline & Middle Lutetian & $\begin{array}{l}\text { Buzet, Paz, Vranje, } \\
\text { Kotle, Draguć }\end{array}$ & Muldini-Mamužić (1965) & pf & & 4 \\
\hline & Upper Lutatian-Bartonian & Izola, Piran & Pavšič (1981) & $\mathrm{np}$ & NP16 & \\
\hline & Upper Lutatian-Bartonian & Piran & Pavšič \& Peckmann (1996) & np & NP16-NP17 & \\
\hline & Middle Eocene & several localities & Piccoli \& Proto Decima (1969) & pf & & \\
\hline & $\begin{array}{l}\text { Middle Lutetian to Lower } \\
\text { Bartonian }\end{array}$ & Pićan-Gračišće & Živković \& Babić (2003) & $\mathrm{pf}$ & P11-P13 & \\
\hline & $\begin{array}{l}\text { Cuisian to Middle/Late } \\
\text { Lutetian }\end{array}$ & several localities & Živković (2004) & $\mathrm{pf}$ & & \\
\hline \multirow[t]{3}{*}{ Northern Kvarner: Krk } & Upper Mid-Eocene & several localities & Šikić (1963) & mo & & \\
\hline & Upper Mid-Eocene & Murvenica & Schubert (1905) & mo & & \\
\hline & Lower Eocene & Omišalj, Baška, Dobrinj & Piccoli \& Proto Decima (1969) & $\mathrm{pf}$ & & \\
\hline Northern Kvarner: Rab & U. Mid-Eocene to U. Eocene & Lopar & Muldini-Mamužić (1962) & $\mathrm{pf}$ & & \\
\hline \multirow[t]{2}{*}{ Pag } & Middle Lutetian-Bartonian & Dinjiška & Benić (1975) & $\mathrm{np}$ & NP15-17 & 5 \\
\hline & Middle Eocene & Gorica, Vrčići & Piccoli \& Proto Decima (1969) & pf & & \\
\hline
\end{tabular}

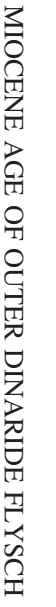


Table 1. Continued

\begin{tabular}{|c|c|c|c|c|c|c|}
\hline Area & Age & Locality & Source & Age based on & Biozone & Notes \\
\hline \multirow{4}{*}{$\begin{array}{l}\text { Northern Dalmatia } \\
\text { (Ravni-Kotari) }\end{array}$} & Upper Eocene & Šopot & Krašeninnikov et al. (1968) & $\mathrm{pf}$ & & \\
\hline & Bartonian to Priabonian & Šopot & Drobne et al. (1991) & $\mathrm{pf}$ & P13-P16/17 & \\
\hline & $\begin{array}{l}\text { Uppermost Lutetian to } \\
\text { Bartonian }\end{array}$ & Sopot & $\begin{array}{l}\text { Benić (1983, fide Marjanac } \\
\text { et al. 1998) }\end{array}$ & np & NP16-17 & \\
\hline & Middle Eocene & Zadar, Zemunik & Piccoli \& Proto Decima (1969) & $\mathrm{pf}$ & & \\
\hline \multirow[t]{14}{*}{ Central Dalmatia } & Lower Tortonian & 'Split E' & de Capoa et al. (1995) & np & NN9 & \\
\hline & Middle Miocene & Mravince & de Capoa et al. (1995) & np & & \\
\hline & Lower Aquitanian & Hvar Island & Puškarić (1987) & np & NN1 & \\
\hline & $\begin{array}{l}\text { Upper Oligocene to Lower } \\
\text { Miocene }\end{array}$ & Jadro quarry & de Capoa et al. (1995) & np & NP25-NN2 & \\
\hline & Upper Rupelian & Gornje Sitno & de Capoa et al. (1995) & np & NP23 & \\
\hline & Bartonian & Hvar Island & Puškarić (1987) & np & NP17 & \\
\hline & $\begin{array}{l}\text { Upper Eocene/Lower } \\
\text { Oligocene }\end{array}$ & Split-Omiš & Grubić \& Komatina (1963) & $\mathrm{pf}$ & & \\
\hline & $\begin{array}{l}\text { Upper Eocene/Lower } \\
\text { Oligocene }\end{array}$ & Hvar Island & Marinčić (1981) & $\mathrm{pf}$ & & \\
\hline & Upper Eocene & Marjan Peninsula in Split & Piccoli \& Proto Decima (1969) & $\mathrm{pf}$ & & 6 \\
\hline & Priabonian & Hvar Island & Krašeninnikov et al. (1968) & $\mathrm{pf}$ & & \\
\hline & Upper Eocene & Hvar Island & Herak et al. (1976) & $\mathrm{pf}$ & & \\
\hline & Upper Priabonian & Split & Jerković \& Martini (1976) & np & NP19/20 & \\
\hline & $\begin{array}{l}\text { Bartonian to Upper } \\
\text { Priabonian }\end{array}$ & Hvar Island & Marjanac et al. (1998) & $\mathrm{pf}$ & NP17-NP19 & \\
\hline & Bartonian & $\begin{array}{l}\text { Orebić (Pelješac } \\
\text { Peninsula) }\end{array}$ & $\begin{array}{l}\text { Benić (1983, fide Marjanac } \\
\text { et al. 1998) }\end{array}$ & np & NP17 & 7 \\
\hline \multirow[t]{10}{*}{ Dalm.-Herz. Zone } & Lower Tortonian & Vukov Klanac & Radoičić et al. (1991) & $\mathrm{np}$ & NN9 & \\
\hline & Lower Tortonian & Bađula & Radoičić et al. (1991) & np & NN9 & \\
\hline & Lower Tortonian & Moševići & Radoičić et al. (1991) & np & NN9 & \\
\hline & Lower Serravallian & Žitomislići & Radoičić et al. (1991) & np & NN5 top & \\
\hline & Lower Serravallian & Gradnići & Radoičić et al. (1991) & np & & \\
\hline & $\begin{array}{l}\text { Lower Serravallian } \\
\text { (?Upper Serravallian) }\end{array}$ & Dabarsko-Fatničko Polje & Radoičić et al. (1991) & np & $\begin{array}{l}\text { NN5 } \\
\quad(? \text { NN7) }\end{array}$ & \\
\hline & Upper Burdigalian & Glavatovići & de Capoa \& Radoičić (1994b) & np & NN4 & \\
\hline & Middle Eocene & Ljubuški & Krašeninnikov et al. (1968) & $\mathrm{pf}$ & & \\
\hline & Middle Eocene & Gornji Studenci & Krašeninnikov et al. (1968) & $\mathrm{pf}$ & & \\
\hline & Middle Eocene & Lukavačko polje & Krašeninnikov et al. (1968) & $\mathrm{pf}$ & & \\
\hline
\end{tabular}




\begin{abstract}
Lower Tortonian
Upper Serravallian

(?Lower Tortonian)
\end{abstract}

Serravallian

Lower Serravallian

(?Upper Serravallian)

Lower Serravallian

Lower Serravallian

Lower Serravallian

Lower Serravallian

Lower Serravallian

Langhian

Miocene

Oligocene

Upper Bartonian to Lower Oligocene

Upper Eocene to Oligocene

Middle to Upper Eocene

Bartonian
Možura North

Možura-Šaško Brdo

W of Grbalj

Konavle

Kotor-Trojica

Trojica-Grbal

Tivat

Petrovac

Kruševica

Grbalj

Kotor-Vrmac

Ulcinj

Ulcinj

Cavtat

several localities

Izvor Česma de Capoa et al. (1995)

Radoičić et al. (1989)

de Capoa et al. (1995)

de Capoa et al. (1995)

de Capoa \& Radoičić (1994a)

de Capoa \& Radoičić (1994a)

de Capoa \& Radoičić (1994a)

de Capoa \& Radoičić (1994a)

de Capoa \& Radoičić (1994a)

de Capoa et al. (1995)

de Capoa \& Radoičić (1994a)

Canović \& Džodžo-Tomić

(1958)

Luković \& Petković (1952)

Krašeninnikov et al. (1968)

Pavić (1970)

de Capoa \& Radoičić (1994a) np

np

np

$\mathrm{np}$

np NN5 top

NN5

NN5

NN5

NN5

np

pf

If

pf

pf, lf

np

NP17

(1) Drobne et al. (1979) report Lower, Middle and Upper Lutetian as well as Upper Eocene planktonic foraminifera and Middle Lutetian nannoplankton from the Pićan flysch. They conclude that age of the strata is Middle Lutetian.

(2) Age younger than the LO of Discoaster lodoensis and D. kuepperi, but older than the FO of Isthmolithus recurvus and may correspond to the zones NP12-15 as re-interpreted by Jerković \& Martini (1976).

(3) Pelagic foraminifera with different biozonal ranges within Middle Lutetian.

(4) Flysch contains arenaceous species of Foraminifera, which markedly contrast the Globigerina in the 'Transitional Beds'. The change appears just above the 'Nummulite breccia' and was observed at several localities in Istria (Buzet, Kotle, Draguć).

(5) Summarizing description of 20 samples. Reworked Paleocene and Lower Eocene forms are also reported.

(6) Reworked Middle Eocene forms are also reported.

(7) 'Similarly as in Split region' (Marjanac et al. 1998). 
deflected (longitudinal) flows (e.g. Magdalenić 1972; Babić \& Zupanič 1983; Orehek 1991). Radial current directions are commonly found in Central Dalmatia, resulting from complex basin floor topography and multiple flow reflection (Marjanac 1990).

A clear NE-directed flow direction can be observed in the $\mathrm{N}$ part of the basin on carbonate debrites and calciturbidites that intercalate into the siliciclastic succession (Engel 1974; Babić \& Zupanič 1996). The coarser-grained debrites range in composition from breccia consisting exclusively of well-cemented Eocene foraminiferal limestone lithoclasts, through mixed ones having much isolated larger foraminifer tests and rhodoliths beside the lithoclasts, to pure grain- or matrix-supported debrites made up of Nummulites tests. Marl and Upper Cretaceous limestone clasts are subordinate (Skaberne 1987; Magdalenić 1972; Hagn et al. 1979; Marjanac \& Marjanac 1991; Radoičić et al. 1991; Tunis \& Venturini 1992; Babić et al. 1995; Marjanac 1996; Tomljenović 2000; Bergant et al. 2003; Pavlovec 2003).

Based on its narrow appearance in map view and the-largely scattered-uniform, longitudinal, SE-directed palaeoflow indicators, the flysch basin has been interpreted as a single major elongated trough (e.g. Marinčić 1981). However, flysch deposits at places rapidly grade upsection into thick sandstone beds deposited in shallow shelf environments, pointing to a complex, dissected basin floor topography with different subsidence histories in the individual domains (Zupanič \& Babić 1991; Babić et al. 1993; Babić \& Zupanič 1998). Rapid upward decrease of water depth in the upper part of the thin flysch sequences has also been observed in other localities at the Island of Pag and in Northern Dalmatia (Lj. Babić, pers. comm. 2005).

\section{Present status of flysch biostratigraphy}

Traditionally, Cenozoic clastic strata stretching along the Adriatic coast have been regarded as Middle to Late Eocene in age. Ages based on planktonic foraminifera and partly on nannofossils range from Early Eocene to Early Oligocene, mostly Bartonian to Priabonian, as summarized in Table 1. Piccoli \& Proto Decima (1969) recognized that the ages become progressively younger towards the SE. Since then, deposition of the flysch in the coastal zone has been commonly explained in terms of a SE-directed diachroneity (Marjanac \& Ćosović 2000; Ćosović et al. in press, and references therein).

Upper Eocene to Lower Oligocene planktonic foraminifera described from Pazin and Motovun localities in Istria and from Hvar Island by Marinčić (1981), and from sites near Split by Grubić \& Komatina (1963), received little attention in subsequent works. Recently, Šparica et al. (2005) reported Upper Oligocene larger foraminiferal, calcareous nannofossil and pollen assemblages from the Pićan profile in Istria.

The first notion of onshore Neogene is from Puškarić (1987) who proved distinct biozones in two nearby profiles on Hvar Island by means of calcareous nannofossils: NP17 (Bartonian) and NN1 (Uppermost Chattian to Lower Aquitanian). Nannofossil studies of de Capoa revealed Early to Middle Miocene ages up to Serravallian from a considerable number of localities in the central and SE part of the flysch basin (Radoičić et al. 1989, 1991; de Capoa \& Radoičić 1994a, b; de Capoa et al. 1995; de Capoa \& Radoičić 2002). Their results are summarized in Table 1. Quantitative test data from nannofossil counting by Radoičić et al. (1989) suggest that Miocene forms constitute only a few percent of the dominantly reworked nannofossil assemblage at any locality.

\section{Methods}

Pelitic rocks were collected for nannofossil analysis throughout the flysch belt (Appendix B). This study does not replace detailed sectionwise biostratigraphic work, yet it represents an exemplary sampling of the most suitable outcrops in the entire basin, performed as such for the first time. Rocks were sampled in five various facies: (1) laminated hemipelagic pelite, (2) pelite rip-up clasts found within sandstone turbidite beds, as well as (3) plastically deformed pelite fragments included in clast-supported carbonate breccia, or in (4) Nummulites debrite, and finally (5) the pelite matrix of matrix-supported debrites made up of limestone clasts and Nummulites tests. The small sampled volume of the clasts (a few $\mathrm{mm}^{3}$ ) required extremely clean conditions during preparation to avoid contamination.

Standard smear slides were prepared from a total of 69 crushed samples using no chemical treatment or centrifugation. Slides were examined under the microscope in normal and cross-polarized lights at $\times 1250$ magnification.

Stratigraphic evaluation was performed for each sample individually, since correlated or thick continuous profiles were not sampled. Evaluation was based on stratigraphic ranges of the taxa alone (from the first (FO) to the last (LO) occurrences, see Appendix A), without using any additional geological information. Species older than the youngest assemblage were also determined and registered, so as to gain information on recycling. In flysch 
deposits where recycled forms are typically the most abundant, species LO-s are only relevant to the age of the 'original' assemblage in the sediment they were eroded from. Sedimentation ages were always established by forms having the youngest FO. In cases where a narrow biozone was proven (e.g. the most frequent NP16), it does not necessarily follow that a 'peak sedimentation event' occurred within that zone.

As many long-lived Cenozoic taxa reach into the Neogene, the identified specimens could be either autochthonous or allochthonous, but both types may also occur together in the sample and cannot be distinguished from each other. This is crucial insofar as abundance of the youngest zonal markers was often found to be extremely low.

Calcareous nannofossil classification in this paper follows Bown \& Young (1997) for the Mesozoic and Young \& Bown (1997) for the Cenozoic. Ranges of Cretaceous species are from Burnett (1998) and Perch-Nielsen (1985a), while Palaeogene species ranges are from Perch-Nielsen (1985b) and Báldi-Beke (1977, 1984). With respect to the Neogene, the latest summary of Young (1998) was used, a work that also took results from the Mediterranean into consideration (Fornaciari et al. 1996; Fornaciari \& Rio 1996). The applied nannoplankton zonation is from Martini (1971).

The nannofossil assemblages examined are mostly of poor preservation and allowed the estimation of abundances only, without exact counting. Our experience has shown that this procedure is good enough for stratigraphic evaluation if flysch samples are dealt with (e.g. Nagymarosy \& Báldi-Beke 1993). Species abundances were variable but generally low, which may depend on their preservation upon long-lasting depositional, diagenetic and weathering processes. Special care was taken to search and identify forms smaller than $10 \mu \mathrm{m}$, too, as most Neogene taxa occur in this size range.

\section{Results of nannofossil analyses}

A total of 69 samples were analysed along the Outer Dinaride coastal range from various tectonostratigraphic units. Four of them were barren of calcareous nannofossils. Estimated taxon abundances are summarized in Table 2. Established stratigraphic ranges for each sample are shown in Fig. 2.

The youngest nannofossil assemblages correspond to the zones NN4-6, placing most of the flysch into the Lower to Middle Miocene, most probably the upper part of this interval, i.e. Langhian to Early Serravallian. In addition, there are many reworked specimens from the Upper
Cretaceous, and from the Middle and Upper Eocene-many of them having non-overlapping stratigraphic ranges. The obtained Miocene ages of deposition are rather uniform throughout the flysch zone.

\section{Istrian Peninsula: Trieste-Koper and Pazin Basins}

Fourteen samples were analysed from the Istrian Peninsula; seven each from the Trieste-Koper Basin (localities Izola, Dekani, Babiči and two nearby sites each at Korte and Momjan) and from the Pazin Basin (Baredine, Kašćerga, Žlepčari, Pićan and Lukačići). Most of them are dominated by Bartonian nannoflora.

At Dekani village (sample TD11), Pemma sp. ind., Chiasmolithus cf. modestus and Sphenolithus spiniger indicate Middle Eocene, whereas at the coastal cliffs of Izola (TD13) the co-occurrence of Chiasmolithus grandis and Reticulofenestra placomorpha corresponds to zones NP16-17, Uppermost Lutetian to Bartonian. The same age was proven at Lukačići (TD171), together with a variable Middle Eocene assemblage. At Pićan (PIC-2), a Bartonian to Priabonian age can be established. Few older Eocene species also occur whose ranges do not reach into zone NP16 (Tribrachiatus orthostylus: NP11-12, middle part of the Ypresian; Discoaster septemradiatus: NP12-14, Upper Ypresian to Lowermost Lutetian). Scarce but ubiquitous reworked Cretaceous forms include Lower and Upper Cretaceous markers as well.

In subordinate quantity, Miocene forms were also discovered throughout Istria, in all but one sample. The assemblage Calcidiscus leptoporus, C. premacintyrei, Coccolithus miopelagicus, Reticulofenestra pseudoumbilicus (partly $>7 \mu \mathrm{m}$ ) and, possibly also six-rayed Discoaster spp., hint at a Miocene age. In the Pićan (PIC-2), Korte (TD15), Babiči (TD16) and Baštini (TD178) localities, specimens of Helicosphaera carteri were also identified. Helicosphaera carteri has its FO at the base of the Miocene worldwide and is a very characteristic form (Photos 13-14 in Fig. 4). Overall, the identified Neogene species define the zones NN4-6 which correspond to Late Burdigalian to Serravallian age. However, at Izola (TD13), Korte (TD15, TD18), Momjan (TD22) and Babiči (TD16), Reticulofenestra pseudoumbilicus is dominated by specimens larger than $7 \mu \mathrm{m}$, such as occur first in the Langhian, close to base NN5. Neogene nannofossils found near Dekani (TD11) are somewhat poorer than at Pićan, indicating either similar or slightly older Early Miocene age. At Lukačići (TD171), the Neogene is only represented by few and small specimens of Reticulofenestra 
Table 2. Distribution of calcareous nannofossils in the Outer Dinaride flysch. Abbreviations: N-Kv: Northern Kvarner area, DHZ: Dalmatian-Herzegovinian zone. See table notes

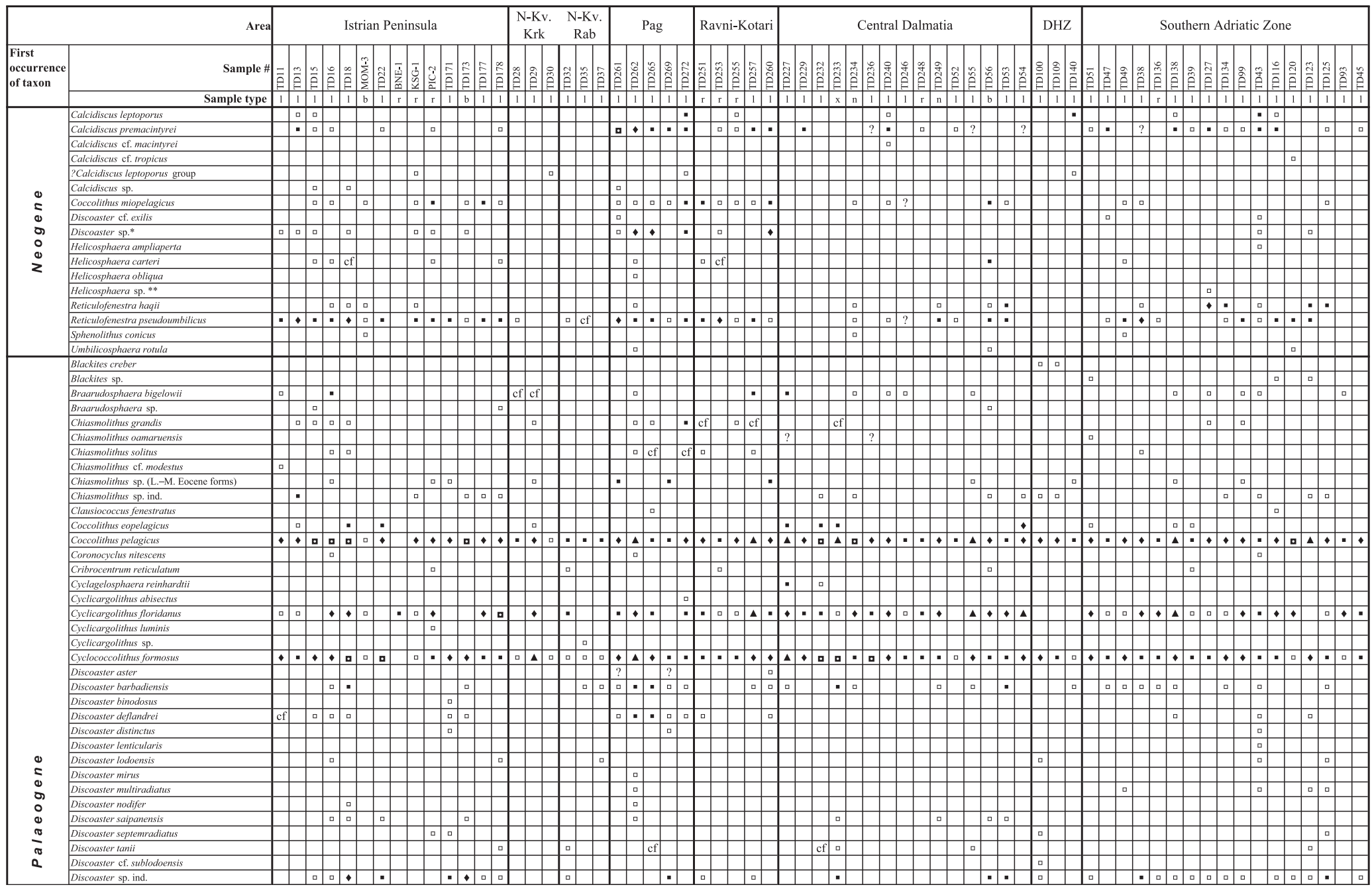




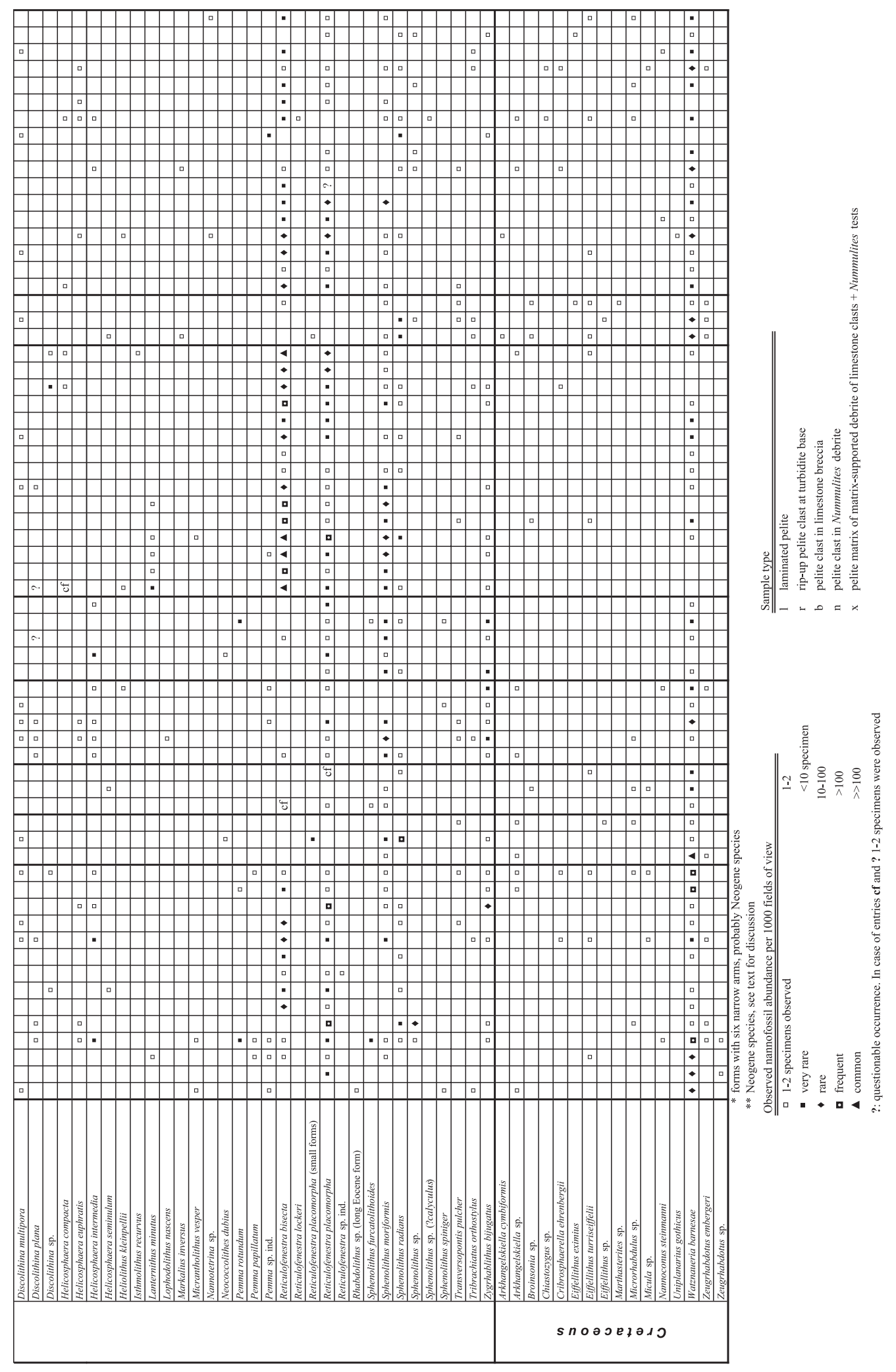




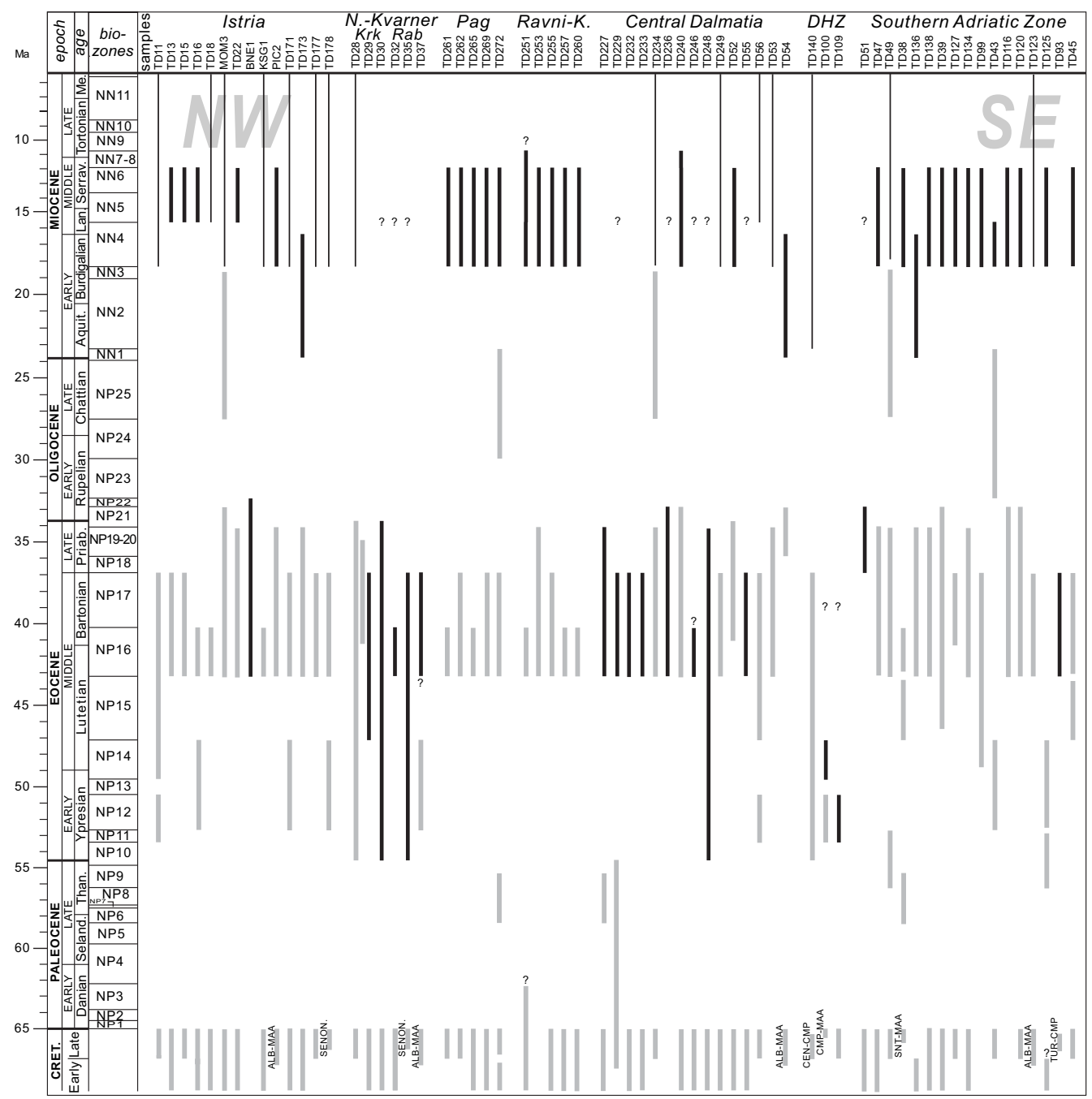

Fig. 2. Stratigraphic position of zonal marker nannoplankton species in the Outer Dinarides. Samples are arranged in columns; bars in each column represent the ranges of zonal markers found in that single sample. N.B.: only species with short zonal ranges are displayed; persistent species living through several epochs are omitted. Black bars mark the youngest assemblages indicating the most probable age of sedimentation. Narrow black lines: Neogene assemblages only comprising species that range beyond the Miocene. Grey bars represent reworked nannoflora. Abbreviations: Ravni-K.: Northern Dalmatia (Ravni-Kotari area), DHZ: Dalmatian-Herzegovinian Zone.

pseudoumbilicus. Of all, the most diverse Miocene assemblage is identified in the Pićan sample (PIC-2), within a rather fresh pelite rip-up clast from the base of a sandstone turbidite bed. Sphenolithus conicus, identified in Istria only in sample MOM-3, ranges from NP25 to NN3 (Upper Chattian to Middle Burdigalian) and is probably reworked due to the presence of Coccolithus miopelagicus, Reticulofenestra haqii and R. pseudoumbilicus in MOM-3.

\section{Northern Kvarner}

Sampling sites are located on Krk and Rab Islands and on the mainland near Crikvenica. Three out of nine samples are barren of nannofossils, the rest being rather poor. They always contain reworked Cretaceous nannofloral elements.

On Krk, near Draga Bašćanska (TD28), only a poor assemblage was found with Arkhangelskiella sp. and abundant Watznaueria barnesae suggesting 
a Late Cretaceous age, together with rare Eocene forms. In the slide, only two specimens of Reticulofenestra pseudoumbilicus $>7 \mu \mathrm{m}$ were found, pointing to zone NN4 or younger, i.e. not older than Burdigalian. A poorly preserved but rather rich Middle Eocene assemblage is found near Bribir (TD29). Although in this sample most species range from Early to Middle Eocene and Sphenolithus radians is rather rare from the NP17 upwards, the FO of the larger forms of Reticulofenestra placomorpha is in NP16. The nannoflora of Bribir likely indicates the zones NP15-17 of MidLutetian to Bartonian age. Another sample from Štale near Bribir (TD30) also contains a very poor assemblage, with the identified Upper Cretaceous, Eocene and Miocene taxa being represented with only one specimen each.

Three samples are from the clastic sediments of Rab Island. Near the town of Rab (TD32), a scarce but diverse Palaeogene nannoflora was established. The characteristic forms of Reticulofenestra placomorpha (FO in NP16), together with Sphenolithus furcatolithoides (LO in NP16), indicate the zone NP16, uppermost Lutetian to Bartonian. A single specimen of Miocene Reticulofenestra pseudoumbilicus was also found here. Similarly, in a poor nannoflora at the port of Lopar (TD35) which contains mostly Senonian and Lower to Middle Eocene nannofloral elements, only one specimen is encountered which resembles Reticulofenestra pseudoumbilicus. A likewise poor assemblage was obtained from sample TD37 from Dumići, $1 \mathrm{~km}$ NW of Supetarska Draga. Among its Eocene species, Discoaster lodoensis has the shortest range, and indicates Late Ypresian to Early Lutetian age (NP12-14). Alternatively, based on Reticulofenestra cf. placomorpha, the Dumići (TD37) assemblage can be evaluated as a younger one (Bartonian), with Discoaster lodoensis then being in reworked position.

\section{Pag Island}

Two profiles of the undisturbed, SW-dipping subvertical flysch succession were sampled on Pag Island. At Stara Vas, $10 \mathrm{~km} \mathrm{SE} \mathrm{of} \mathrm{Pag} \mathrm{town,} \mathrm{three}$ samples were taken 9,45 and $92 \mathrm{~m}$ above the foraminiferal limestone (TD261, TD262 and TD265, respectively). Two samples stem from the coastal profile at Vlašići, collected 17 and $34 \mathrm{~m}$ above the limestone top (TD269 and TD272, respectively).

In all samples, the nannoflora is very diverse, and a particular abundance was observed in the middle portion of the Stara Vas profile (TD262). Overall, the observed Cretaceous elements are rare, but indicate reworking of Upper Cretaceous assemblages (Arkhangelskiella sp., Microrhabdulus sp.). The majority of the nannofossils are Middle
Eocene and most probably belong to zones NP16-17, i.e. Uppermost Lutetian to Bartonian. In the upper sample from Vlašići (TD272), the dominant Middle Eocene assemblage and the isolated Lower and Upper Cretaceous forms are accompanied by single specimens of Heliolithus kleinpelli from the Late Paleocene (NP6-9) and Cyclicargolithus abisectus most probably from the Chattian (NP24-NN1).

The Neogene part of the assemblages consists of three to five species which are identical in all samples throughout. Of these, Calcidiscus premacintyrei is characterized by the shortest range, i.e. Late Burdigalian and Early Serravallian (zones NN4-6). The remaining Neogene species have their FO mainly in the Early Miocene but FO of Reticulofenestra pseudoumbilicus $>7 \mu \mathrm{m}$ is close to the base of zone NN5, in the Langhian. Although Neogene taxa make up only a very small part of the whole of the assemblages, in sample TD262 they appear to be more abundant than elsewhere in Pag together with a similarly higher abundance of Palaeogene forms.

\section{Northern Dalmatia (Ravni-Kotari)}

The nearly complete profile exposed by the Šopot railway cut was sampled at four sites $(28,116$, 130 and $383 \mathrm{~m}$ above the foraminiferal limestone) and an additional sample is from a road cut of the recently constructed Zagreb-Split motorway near Islam Latinski, beneath the Suhovare bridge. Except the section top, all Šopot samples were extracted from fresh rip-up pelite clasts at the base of graded turbidite beds.

The observed nannofossil assemblages bear close resemblance to each other. Reworked Cretaceous coccoliths are rare compared to other parts of the basin system, being represented by Watznaueria barnesae. The Palaeogene nannoflora is rather diverse, yet uniform between samples. It is not older than latest Lutetian (zone NP16), as proven by samples bracketing the Šopot section at its base and top (TD251, TD257) and by the Suhovare outcrop (TD260). Although in none of the two intermediate samples in the Šopot section can the Eocene nannoflora be narrowed to NP16, a younger Palaeogene age for these assemblages is unlikely.

Neogene species identified in this unit are similar to those appearing in the Istrian Peninsula and Pag Island. Calcidiscus premacintyrei, Coccolithus miopelagicus and Reticulofenestra pseudoumbilicus occur in each sample in low yet meaningful amounts. Six-rayed Discoaster spp. occur in both profiles, while Calcidiscus leptoporus and Helicosphaera carteri were identified in the Šopot section only. The Neogene assemblage is 
assigned to the NN4-6 zones, indicating Late Burdigalian to Early Serravallian age.

\section{Central Dalmatia}

In Central Dalmatia, near the cities of Split and Omiš, 15 samples were analysed. The very scarce reworked Cretaceous nannofossils are represented mostly by Watznaueria barnesae, and Eocene nannofossils constitute the vast majority of the diverse and mostly rich assemblages.

Four sites near Mravince (TD227, TD232, TD233 and TD234) reveal a rather similar Palaeogene nannoflora, composed of very abundant but poorly preserved uppermost Lutetian to Priabonian forms. In addition, older index species also appear in Mravince: Heliolithus kleinpelli (NP6-9, Upper Paleocene) and Cyclagelosphaera reinhardtii, Albian to Paleocene. In the marl quarry at Mravince (TD229), recrystallized coccoliths dominate the sample and indicate Middle to Late Eocene age (NP16-21). The three most frequent species (Reticulofenestra bisecta, Coccolithus pelagicus and Cyclococcolithus formosus) share a common size and shape, strongly suggesting hydrodynamic control on species composition. Only a few specimens of Calcidiscus premacintyrei were found in the sample from the Mravince quarry (TD229), which may place the marl to the zones NN4-6.

We established Miocene ages with more confidence only in a part of the localities. In Jadro Valley, at Vrilo Jadro (TD240), besides Eocene species which define only a broad range of zones NP16-21 (Bartonian to Priabonian), five Neogene taxa also occur. Of these, Calcidiscus premacintyrei and Reticulofenestra pseudoumbilicus define the zones NN4-6, placing the age of these beds between Late Burdigalian and Early Serravallian.

Of the samples taken at Mravince, a pelite lithoclast extracted from a grain-supported Nummulites debrite (TD234) yielded comparatively abundant Neogene nannoflora: Sphenolithus conicus (Upper Chattian to Middle Burdigalian; probably reworked), as well as Coccolithus miopelagicus, Reticulofenestra haqii and R. pseudoumbilicus, corresponding to an age not older than Late Burdigalian.

Another pelite lithoclast (TD56) from a limestone breccia exposed by the large abandoned quarry of Omiš also yielded rather diverse Neogene nannofossils; Helicosphaera carteri, Coccolithus miopelagicus, Reticulofenestra haqii, R. pseudoumbilicus and Umbilicosphaera rotula, which suggest biozone NN5 or younger, i.e. at least Langhian age.

In other Central Dalmatian localities examined, either an abundant but monotonous and poorly preserved nannoflora occurs displaying Middle to Late Eocene age (the larger pit of the Jadro quarry,
TD236), or solely a poor Eocene assemblage is encountered. Such extremely scarce nannoflora was found at several localities over larger alongstrike distances $(80 \mathrm{~km})$ : in the town of Solin in the Voljak Street section (TD248), a laminated pelite sample in the large abandoned quarry of Omiš (TD55), road cut at Porat near Živogošće (TD52) and in a metre-sized, grey, angular marl block included in thick limestone debrite at Gizdići near Klis (TD246).

\section{Dalmatian-Herzegovinian Zone}

In the densely imbricated thrust belt of the Dinaride carbonate platform in Southern Herzegovina, a single sample was analysed from Crnići village near the Neretva valley (TD140). The diverse, reworked Cretaceous nannofossil association hints at an Upper Cretaceous source older than Maastrichtian. A scarce Lower to Middle Eocene nannoflora is also present. Indication for the Neogene age of the rocks is provided by several specimens of Calcidiscus leptoporus ranging from the Early Miocene to recent (NN2-21).

Further to the SE, a narrow flysch zone is exposed in front of the Kuči Thrust that streches NW-SE from the Nevesinjsko Polje to Podgorica. Two samples were taken close to Podgorica; from a fault-bounded block standing out from the Zeta Valley $3 \mathrm{~km} \mathrm{NW}$ of Spuž village (TD100), and in Medun village, $2 \mathrm{~km}$ ENE of Podgorica (TD109).

Both profiles contain reworked Upper Cretaceous taxa; age ranges can be probably narrowed to Campanian-Maastrichtian at Spuž. Here the relatively rich nannoflora is Lower to Middle Eocene and consists of several taxa with overlapping stratigraphic ranges (Table 2). Discoaster lodoensis and D. septemradiatus are markers of zones NP12-14 indicating Late Ypresian to Early Lutetian age. Important is a single specimen of Discoaster cf. sublodoensis, which marks the base NP14, the base of the Lutetian. The Ypresian Tribrachiatus orthostylus (NP11-12) is also part of the assemblage. Such a complexity is best explained by a multiple reworking history and will be discussed later.

In Medun profile (TD109), the Palaeogene assemblage is scarce but Tribrachiatus orthostylus occurs here as well, the Ypresian index species of the zones NP11-12.

\section{Southern Adriatic Zone}

A common feature of the 17 flysch samples taken in the Southern Adriatic Zone is their paucity of Cretaceous forms. In two samples, they are entirely absent (Ulcinj, TD99; Stari Bar, TD116). Nevertheless, reworked Upper Cretaceous index forms are identified in some cases and they preferentially occur in 
the southern part of the zone. Eiffellithus eximius and Uniplanarius gothicus are characterized by the shortest range of all, and indicate reworking from Turonian-Campanian and SantonianMaastrichtian strata, respectively. Two samples bear Nannoconus steinmanni, hinting at reworking from Lower Cretaceous sediments (TD125, TD136).

In all samples, Eocene forms are predominant, albeit different in origin. Often the zones NP16-17 were registered (Uppermost Lutetian and Bartonian) but in other cases merely a longer interval could be given (NP16-20 or NP16-21).

Three, partly overlapping biozones can be proven at the base of the Klezna profile (TD125) from the Upper Paleocene to the Lutetian (range of Discoaster multiradiatus is NP9-11, that of Tribrachiatus orthostylus is NP11-12 and that of Discoaster lodoensis and Discoaster septemradiatus is NP12-14). This peculiar overlap offers a wide range of interpretations with respect to the age and recycling history of the sediment and will be discussed in the subsequent part.

A variety of reworked Palaeogene zone markers have been encountered throughout the Southern Adriatic Zone. Specimens of Discoaster multiradiatus (NP9-11; Paleocene) occur in sample TD49 (Dubravka). The NP12-14 zones are proven from the Zaljevo profile (TD43) corresponding to Upper Ypresian and earliest Lutetian. In addition, sample TD45 yielded Nannotetrina sp., a marker for NP15 (Mid-Lutetian). In TD51, an Upper Eocene zonal marker was encountered, Chiasmolithus oamaruensis (NP18-22). Oligocene marker taxa are extremely rare in the entire flysch belt, thus the finding of Reticulofenestra lockeri (NP23-NN1; Middle Rupelian to Lower Aquitanian) in sample TD43 and Sphenolithus conicus (NP25-NN3; Chattian to Middle Burdigalian) in sample TD49 is of particular importance.

Thirteen out of 17 samples of Miocene forms are sufficiently represented, whereas in TD93 they are missing, in TD51 there is one specimen and in TD45 and TD136 there are two specimens. Miocene species characteristic of zones NN4-6 indicate depositional ages not older than Late Burdigalian. In Zaljevo (TD43), occurrence of two specimens of Helicosphaera ampliaperta (range NN2-4) is of particular importance as together with other Neogene species (Calcidiscus leptoporus, C. premacintyrei and possibly also six-rayed Discoaster spp.) the stratigraphic position can be ascertained to the zone NN4 (Upper Burdigalian to Lower Langhian).

\section{Nannofossil preservation}

Our results reveal that the Neogene calcareous nannofossil assemblages are surprisingly low, both in abundance and diversity. Accurate dating of the Outer Dinaride Neogene successions awaits further bio- and chronostratigraphic control.

Physical and chemical processes operating during flysch formation and diagenesis influence the composition of the nannoflora (disintegration, dissolution, recrystallization) and probably account for the observed overall scarcity of the nannoflora (e.g. Thierstein 1980; de Kaenel \& Villa 1996). High degree of reworking of older species, together with evidence for diagenetic processes as indicated by carbonate-cemented turbidite beds, carbonate veinlets dissecting the turbidites, bent mica plates and severely etched surfaces of susceptible heavy mineral grains (amphibole, staurolite, garnet), are in accordance with the poor preservation of the nannoflora. Indeed, samples from pelite clasts, embedded in breccias or wellcemented sandstones and presumably preserved from corrosive solutions, proved to yield more diverse Neogene assemblages than those found in laminated pelites (e.g. samples MOM-3, KSG-1, PIC-2, TD253, TD255, TD234, TD56; see Table 2).

\section{Cretaceous to Palaeogene nannofloral elements}

Most nannofossil assemblages are mixed, with evidence for recycling of specimens from pre-existing sediments. Cretaceous forms commonly occur together with the Cenozoic ones. Common longlived Cretaceous species, e.g. Watznaueria barnesae, are ubiquitous. Among the shorter-range taxa, Nannoconus steinmanni indicates Lower Cretaceous, and several Upper Cretaceous markers occur as well (Arkhangelskiella sp., Microrhabdulus sp., Eiffellithus turriseiffelii). A limited number of characteristic taxa prove the availability of Lower Palaeogene sediments to erosion: Heliolithus kleinpelli, Discoaster multiradiatus, Discoaster lenticularis (Paleocene), Tribrachiatus orthostylus (Lower Eocene) and Discoaster lodoensis (Ypresian to lowermost Lutetian). All these Lower Palaeogene species are large in size and, according to our experience, fairly resistant against dissolution.

In spite of reworking, an attempt was made to identify characteristic Palaeogene assemblages preserved in the entire sample material. The most frequent Middle Eocene forms can be placed into the NP16 zone in several localities. Often, NP16 zone was recognized using the FO of Reticulofenestra placomorpha and the LO-s of Sphenolithus furcatolithoides and Chiasmolithus solitus. Whenever the latter species were not registered, the possible age of that assemblage could only be bracketed with lower precision, which might then extend from 
the NP16 upward into NP17 or even longer to the Late Eocene or Early Oligocene. We used the LO of Chiasmolithus grandis for the end of NP17, that of Discoaster saipanensis and/or Discoaster barbadiensis for the NP20/NP21 boundary (close to the Eocene/Oligocene boundary), and that of Cyclococcolithus formosus and Reticulofenestra placomorpha for the end of NP 21 and NP 22 zones, respectively, in the Early Oligocene. As for Late Eocene, a single, poorly preserved specimen of Chiasmolithus oamaruensis occurred in the entire studied material, as previously reported from Oprtalj, Istria (Benić 1991), Split (Jerković \& Martini 1976) and Hvar (Marinčić 1981) in Central Dalmatia, and the North Mozura section in the Southern Adriatic Zone as well (de Capoa et al. 1995). Isthmolithus recurvus (NP20-22), which indicates Late Priabonian to Middle Rupelian, was found at Omiš (sample TD54).

Species of even longer ranges spanning from the Middle Eocene to various levels in the Miocene include the ubiquitous and highly abundant Cyclicargolithus floridanus and Coccolithus pelagicus. Also Sphenolithus moriformis, Helicosphaera euphratis, H. intermedia, Discolithina div. sp., and Transversopontis sp. appear in a number of samples. It is evident that among them there may exist specimens indistinguishably that lived in a given part of the Eocene, Oligocene or Miocene.

In the Oligocene nannofossil zonation, there are only a few markers to appear, due to the global cooling trend following the terminal Eocene events (e.g. Pomerol 1985). These few FOs are typically represented by the low-latitude forms of Sphenolithus. Of them, Sphenolithus conicus, ranging from NP25 to NN3, has been found in Istria, Central Dalmatia and the Southern Adriatic Zone. Further short-range index species include Cyclicargolithus abisectus and Reticulofenestra lockeri, and in this study both species have been encountered on Pag Island and in the Southern Adriatic Zone.

The scarcity of Paleocene nannofloral elements is probably due to the unavailability of Paleocene sediments for the reworking processes. Normally, both the diversity of Paleocene zonal markers and their resistance would permit them to be wellrepresented in Cenozoic flysch sediments.

\section{Distribution of nannofossil age ranges and sediment recycling}

Apart from significant Upper Cretaceous and Middle Eocene nannofloral components, and the presence of Lower to Middle Miocene nannoflora, there are index species of Paleocene, Lower and Upper Eocene and Oligocene present, too (Fig. 3). Unusual composition of some assemblages depicts characteristic age distribution patterns, whether or not Neogene forms are recognized in that sample (Fig. 2). We can discern two types.

(1) Joint occurrence of Palaeogene species with no overlapping age ranges. We observe this in Istria (TD11, TD171), Northern Kvarner area (TD37), Pag Island (TD272) at Mravince in Central Dalmatia (TD227), and in the Southern Adriatic Zone (TD38, TD43, TD45).

(2) A blurred, consecutive overlap pattern of several index species: Discoaster multiradiatus (NP9-11), Tribrachiatus orthostylus (NP11-12), Discoaster lodoensis and D. septemradiatus (NP12-14) and Discoaster cf. sublodoensis (NP14-15) occur together, in addition to Lower and Upper Cretaceous markers. Such mixed assemblages were encountered both in the Zeta Valley in the Dalmatian-Herzegovinian Zone (TD100) and in the Southern Adriatic Zone (TD125). Evidently, the partly overlapping ranges of these species can be combined to a number of species coexistence patterns, but recycling remains necessary to explain overall species composition. The resulting maximum time span for the Early Palaeogene 'cascade' alone may cover $c$. $9 \mathrm{Ma}$, but presence of further non-overlapping taxa suggests a more or less continuous and by all means cannibalistic sedimentation. Both types of age distribution provide an insight into the progressive Cretaceous to Cenozoic sediment reworking history. Actual sedimentation ages of the flysch probably become younger towards the foreland, along with the increasing number of reworked 'fossil' biozones. During thrusting, the deposited flysch was off-scraped and reworked, its material acting as a source for the yet younger flysch deposits.

We need to stress that the few, comparatively thick flysch profiles available (e.g. Brkini, Šopot, Skradin, Split, Petrovac) all display a limited thickness (c. 300-500 m), which is not enough to accommodate the time represented by the full nannofossil age spectrum assuming typical flysch sedimentation rates $(50-2000 \mathrm{~m} / \mathrm{Ma}$; Einsele 1992, p. 389). De Capoa et al. (1995) documented the nannofossils of the $140 \mathrm{~m}$ thick Petrovac profile in the Southern Adriatic. With nearly equidistant sampling, they obtained successively younger assemblages upsection from the Upper Thanetian to the Langhian, which spans c. $40 \mathrm{Ma}$ implying a sedimentation rate of only c. $3.5 \mathrm{~m} / \mathrm{Ma}$, which is not realistic for submarine fan depositional setting. Judging from their data, at Petrovac there are either undiscovered, short-lived unconformities or, more likely, most of the older ages come from reworked nannofossils due to extensive dilution. 


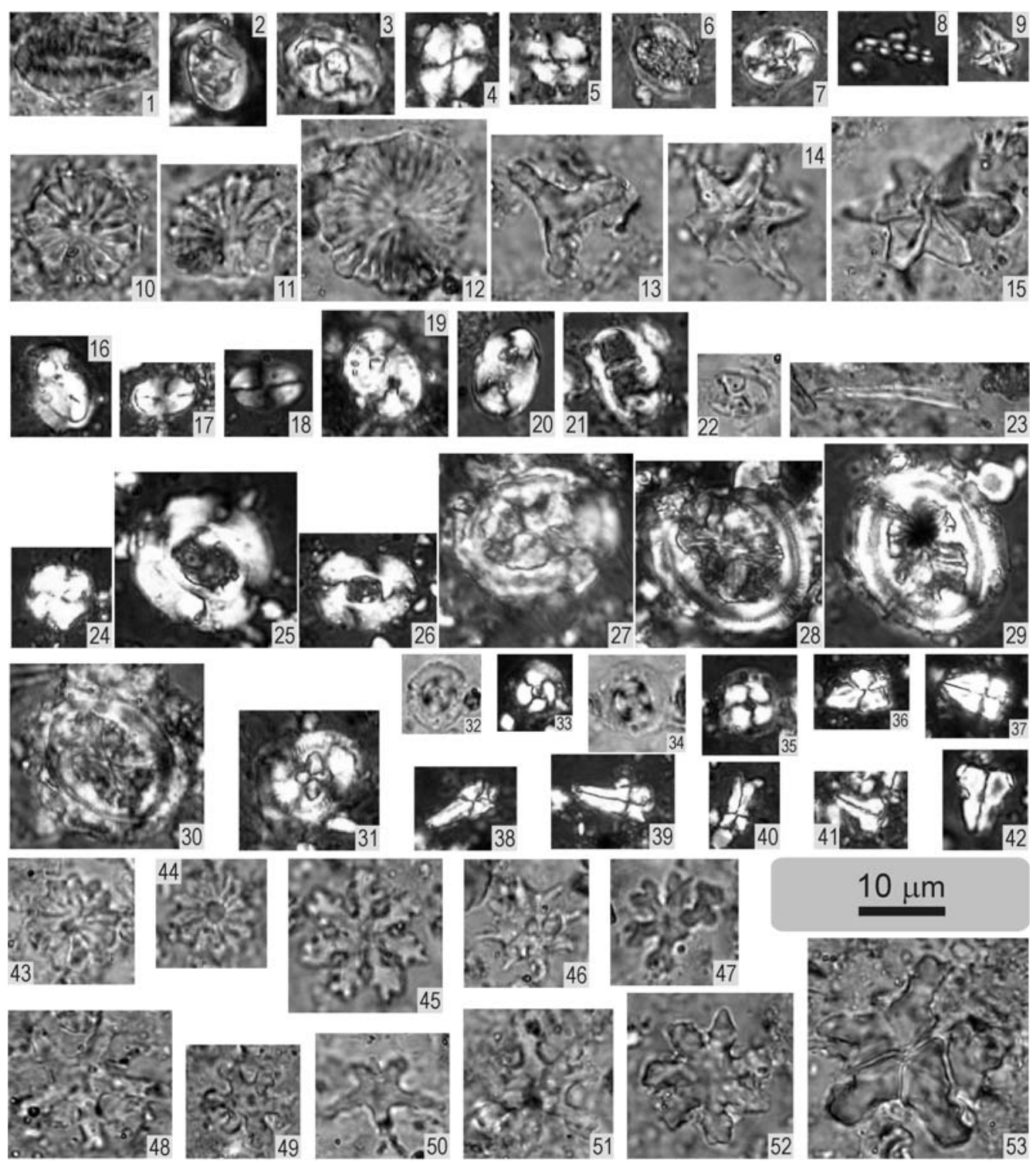

Fig. 3. Cretaceous (1-9), Paleocene (10-12), Lower Eocene (13-15) and diverse Palaeogene (15-53) nannoplankton in the Outer Dinaride flysch. Abbreviations refer to light types used: PP, plane-polarized; SX, slightly cross-polarized; XP: cross-polarized. 1, Nannoconus steinmanni (Sample TD43, SX); 2-3, Zeugrhabdotus embergeri (2: TD16, XP; 3 : TD123, XP); 4-5, Watznaueria barnesae (4: TD16, XP; 5: TD262, XP); 6, Cribrosphaerella ehrenbergii (TD123, SX); 7, Eiffellithus turriseiffelii (TD43, XP); 8, Microrhabdulus sp. (TD18, XP); 9, Micula sp. (TD123, XP); 10-11, Discoaster multiradiatus (10: TD262, PP; 11: TD123, PP); 12, D. lenticularis (TD43, PP); 13, Tribrachiatus orthostylus (TD262, PP); 14-15, Discoaster lodoensis (14: TD16, PP; 15: TD43, PP); 16, Helicosphaera compacta (TD43, XP); 17-18, Discolithina plana (17: TD261, XP; 18: TD16, XP); 19, Transversopontis pulcher (TD262, XP); 20, Transversopontis sp. (TD15, XP); 21, Lophodolithus nascens (TD262, XP); 22, Neococcolithes dubius (TD253, PP); 23, Blackites sp. (TD123, PP); 24, Reticulofenestra bisecta (PIC-2, XP); 25-26, R. placomorpha (25: TD16, XP; 26: TD18, XP); 27-30, Chiasmolithus grandis (27: TD16, XP; 28: TD16, XP; 29: TD15, XP; 30: TD262, SX); 31, Chiasmolithus sp. (TD43, XP); 32-35, Cyclococcolithus formosus (32-33: TD43, PP and XP resp.; 34-35, TD16, PP and XP resp.); 36-39, Sphenolithus radians (36: TD123, XP; 37: TD123, XP; 38: TD16, XP; 39: TD16, XP); 40, S. furcatolithoides (TD16, XP); 41-42, Zygrhablithus bijugatus (41: TD261, XP; 42: TD16, XP); 43-44, Discoaster barbadiensis (43: TD262, PP; 44: TD262, PP); 45, D. mirus (TD262, PP); 46, D. saipanensis (TD262, PP); 47 and 49, D. deflandrei (both TD262, PP); 48 and 50-51, D. tanii (48: TD123, PP; 50: TD123, PP; 51: TD123, PP); 52-53, D. nodifer (52: TD262, PP; 53: TD18, PP). 


\section{Miocene nannofossils}

The majority of samples contains nannofossils, suggesting Miocene age. In the NW portion of the Dinaride foreland basin, this paper reports such fossils for the first time from onshore outcrops. Unfortunately, these crucial forms are small, very rare, often poorly preserved and tend to comprise morphologically variable species.

In our experience however, most standard flysch nannofossil stratigraphic studies typically ignore or overlook such 'inconvenient'-forms. As they have outstanding importance in Dinaride flysch stratigraphy, they have to be discussed in more detail.

The most common placolith species encountered in the Outer Dinarides are species of the Calcidiscus group, Reticulofenestra pseudoumbilicus, $R$. haqii and Coccolithus miopelagicus. As demonstrated by Young (1998), however, these often exhibit a wide variety in shape and size, hampering exact taxonomic identification. In fact, morphologically related forms do occur in the Palaeogene, albeit a very rare phenomenon, e.g. Reticulofenestra dictyoda (Deflandre in Deflandre \& Fert) Stradner in Stradner \& Edwards (see Varol 1998). The comparatively high frequency of this type of placolith met in the Dinaride samples strongly argues for their Miocene rather than Eocene age. Among these species, Reticulofenestra pseudoumbilicus $>7 \mu \mathrm{m}$ is the most common one. Regarding the Calcidiscus species, C. leptoporus and C. macintyrei are of very low frequency, and only a few specimens were found in the entire material. On the contrary, $C$. premacintyrei has often been registered, even though it occurs in its less typical varieties. The occurrence of Coccolithus miopelagicus is well demonstrated (Fig. 4).

The genus Helicosphaera is represented by several species, and two of them have a Miocene FO-Helicosphaera carteri and $H$ ampliaperta. Unfortunately, Helicosphaera is just moderately resistant to dissolution and overcalcification, resulting in poor preservation. This makes $H$. carteri difficult to identify, but the flange and the central area with the two pores are visible (Fig. 4). A third species of Helicosphaera is characterized by prominent central openings and a conjunct central bar which suggests Neogene age despite the poorly preserved flange at the rim of the coccolith (Photo 12 in Fig. 4).

Among the Discoaster species, a rather frequent type occurs with five or six narrow rays. Their preservation is always very poor, with heavily overcalcified specimens, and ends of their arms mostly broken off. Although this type exists also in the Eocene, Discoaster tanii and similar forms are generally very rare. In fact, in the Miocene the most frequent Discoaster spp. are 5- or 6-rayed with bifurcations at the end of their arms, represented by a wide variety of species. Among them the Discoaster exilis group is the most probable candidate (e.g. with D. aulakos Gartner 1967 in Young 1998, p. 257), but they bear close resemblance to D. variabilis Martini \& Bramlette 1963 as well. If bifurcation is not visible, it is either broken off or it is a primary characteristic (e.g. such as that of D. bellus Bukry \& Percival 1971). With respect to decisive specific characteristics, the central area (with or without knob), the inter-ray area (rounded or rather $\mathrm{V}$-shaped), the arms (with the sides tapering, parallel or curving) and the ending of the arms (bifurcating or not) were considered. In spite of poor preservation of the Discoaster spp. under discussion, their characteristics suggest Miocene age.

Overall, the identified Miocene nannofossil species correspond to the zones NN4-6 (based on Calcidiscus premacintyrei), but they are probably not older than NN5 as Reticulofenestra pseudoumbilicus $>7 \mu \mathrm{m}$ occurs first in this zone. Consequently, whenever Neogene taxa are present, the age of clastic sedimentation in the Adriatic onshore area is probably not older than Langhian.

As a result of the surprisingly rare occurrence and poor preservation of the nannofossils and occasionally wide specific morphological variability, the Neogene age of deposition cannot be unambiguously confirmed. Noticeably, the observed problematic forms are unknown in the Bakony Eocene Basin in Hungary although it exhibits rather comparable Middle Eocene nannofossil assemblages to those in the Outer Dinarides (BáldiBeke 1984; Báldi-Beke \& Báldi 1991).

Research is in progress to address this stratigraphic problem further: to look at whether the roles of hydraulic, diagenetic and weathering processes exert a fundamental control on the assemblage compositions.

\section{Implications for palaeoenvironment}

\section{Pelagic environment with neritic influence}

Despite sediment mixing and reworking, it is evident that the most frequent forms pertain to a Middle Eocene assemblage. The species composition is rather complex and exhibits common placoliths. Some species possess a specific habitat and are thus of ecological importance, such as the nearshore taxa Neococcolithes dubius, Pemma sp., Discolithina, Transversopontis and holococcoliths, e.g. Zygrhablithus bijugatus (e.g. Perch-Nielsen 1985b). Although abundance of these nearshore taxa is low in all samples, as many of them are at the same time particularly susceptible to dissolution, it can be assumed that their initial abundance 

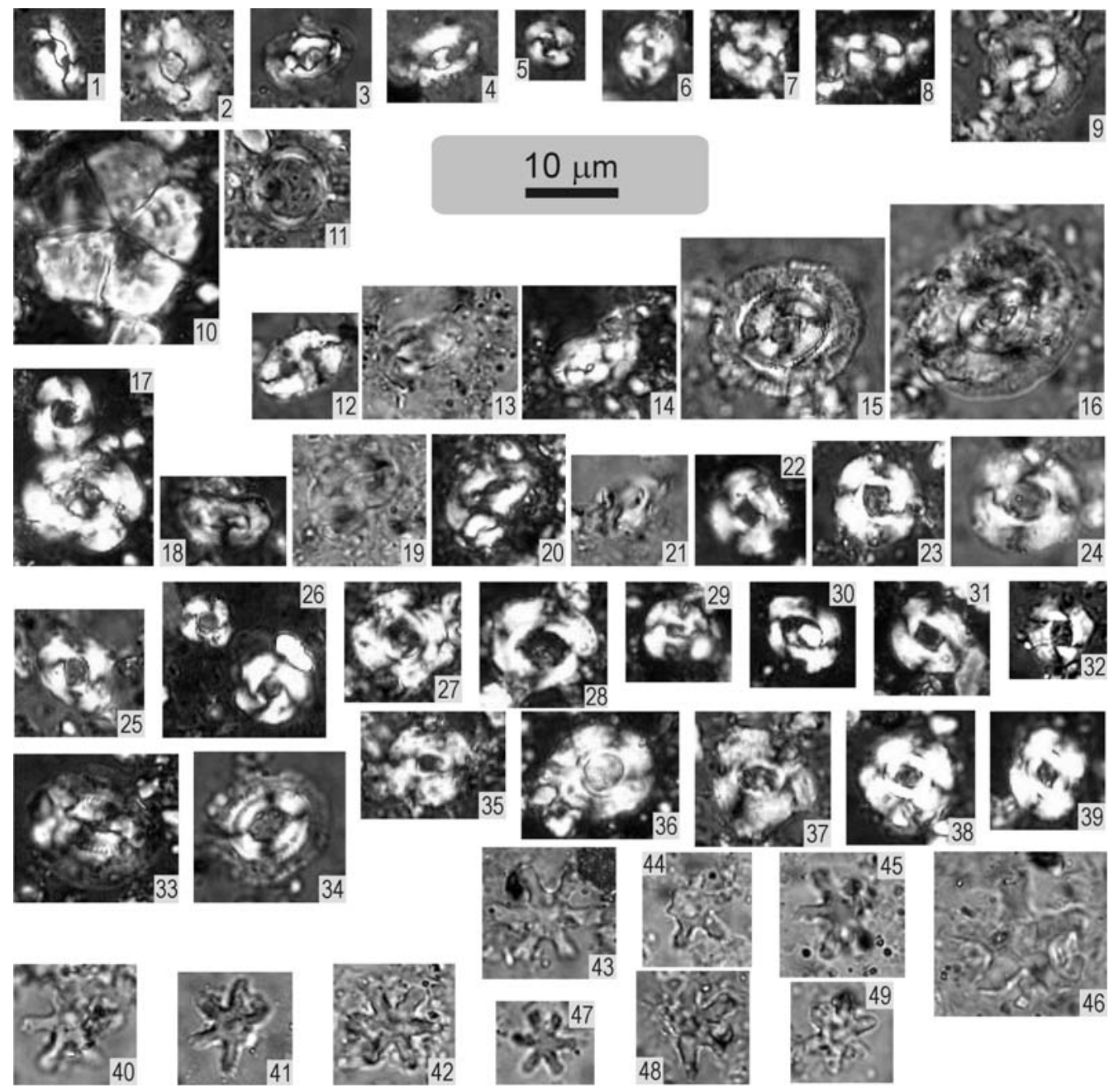

Fig. 4. Palaeogene to Neogene (1-11) and Neogene (12-46) nannoplankton of the Outer Dinaride flysch. Designations as in Fig. 3. 1-2, Helicosphaera euphratis (1: Sample TD43, XP; 2: Sample TD262, XP); 3-4, H. intermedia (3: TD127, XP; 4: TD43, XP); 5-7, Cyclicargolithus floridanus (5-6: PIC-2, XP; 7:

TD261, XP); 8-9, Coccolithus pelagicus (8: TD261, XP; 9: TD262, SX); 10, Braarudosphaera bigelowi (TD127, XP); 11, Coronocyclus nitescens (TD262, SX); 12, Helicosphaera sp. (flange poorly preserved but note prominent central openings and the conjunct central bar, TD127, XP); 13-14, H. carteri (13: TD15, PP; 14: TD15, XP); 15-16, Coccolithus miopelagicus (15: TD262, PP; 16: TD16, XP); 17, Reticulofenestra pseudoumbilicus $>7 \mu \mathrm{m}$ (above; together with the Palaeogene $R$. placomorpha, below, TD15, XP); 18-20, Helicosphaera carteri (18: TD16, XP; 19: TD262, PP; 20: TD262, XP); 21, H. obliqua (TD262, SX); 22-26, Reticulofenestra haqii (22: TD16, XP; 23: TD18, XP; 24: TD262, XP; 25: TD123, XP; 26: TD43, XP, 2 specimens); 27-32, $R$. pseudoumbilicus $>7 \mu \mathrm{m}$ (27: TD261, XP; 28: TD261, XP; 29: TD261, XP; 30: TD251, XP; 31: TD16, XP; 32: TD15, XP); 33-34, Coccolithus miopelagicus (33: TD16, SX; 34: TD16, SX); 35-37, Calcidiscus premacintyrei (35: TD261, XP; 36: TD262, XP; 37: TD261, XP); 38-39, Calcidiscus sp. (38: TD15, XP; 39: TD261, XP); 40-44 and 48-49, Discoaster spp. 6-ray (40: PIC-2, PP; 41: TD15, PP; 42: TD18, PP; 43: TD123, PP; 44: TD253, PP; 48 and 49: TD18, PP); 45-46, Discoaster spp. 5-ray (45: TD15, PP; 46: TD123, PP); 47, Discoaster sp. $7 \mu \mathrm{m}$, 6-ray (TD261, PP). 
was higher in the sediment, which in turn calls for a remarkable neritic influence on sedimentation in the Eocene. The scarce Neogene assemblage does not provide useful environmental information.

\section{Neogene: absence of planktonic foraminifera, presence of nannofossils}

Preliminary examination of our samples containing Miocene nannofossils did not yield any planktonic foraminifera younger than Middle Eocene in Istria and Kvarner or younger than Early Oligocene in the Southern Adriatic (V. Cosović, pers. comm. 2006; F. Rögl, pers. comm. 2007). To our knowledge, no such data have been published from onshore localities, either (Table 1).

The characteristic depth habitat of several planktonic foraminifer species can preclude their survival in relatively shallow waters. Most species require oceanic salinities near 35-36\%o, and a few of them can tolerate salinities down to $30.5 \%$, and can thus only penetrate coastal waters if they are sufficiently clear and lacking in turbidity (Haynes 1981, p. 330). Nannoplankton, in contrast, tolerate reduced salinity although diversity can be reduced in brackish water under elevated freshwater input (e.g. Olszewska \& Garecka 1996; Schulz et al. 2005).

In places, the Outer Dinaride flysch deposits rapidly grade into shallow marine deposits. Sand-rich shallow shelf environments influenced by nearby river mouths have been described from the Islands of Rab and Pag and from Northern Dalmatia (Zupanič \& Babić 1991; Babić et al. 1993; Babić \& Zupanič 1998). Facies architecture of clastic deposits in Northern and Central Dalmatia is also well documented (e.g. Postma et al. 1988; Mrinjek 1993; Marjanac 1996), and show fan deltas prograding on the flysch succession. The increasing proximity of the alluvial environments implies significant freshwater input which could have a profound effect on salinity and thus adversely influenced foraminifer distribution.

\section{Heterochronous redeposition}

As a prominent feature, debrites of several metres of thickness that intercalate the turbiditic flysch successions of the Outer Dinarides often contain isolated tests of Eocene larger foraminifera. In spite of attempts to date the depositional age by means of such fossils (Pavić 1970), they are evidently allochtonous in a submarine fan setting. Pavlovec (2003) noted that Nummulites assemblages found in flysch deposits Dinarides-wide were in fact no true biocoenoses but rather mixed in composition with unusual species proportion as compared to those in the limestones. Indeed, derived fossils may occur in a state of preservation as good as or better than that of the original rock, and the reworked fauna may be more diverse and contain a much higher proportion of planktonics than that of the source rock (Curry 1982).

Ample examples from the Outer Dinarides and from comparable settings in the surrounding areas show that larger, smaller and also pelagic foraminifer tests can survive diagenesis in unconsolidated sediment and be reworked into younger strata: (i) Lower Eocene (Upper 'Cuisian') flysch of Trnovo, SW Slovenia contains Lower to Middle Cuisian larger foraminifera: Nummulites subdistans (Pavlovec 2006); (ii) planktonic foraminifera in the flysch of Pićan are uniformly Middle Lutetian in age but if examined in detail, they belong to various biozones (Pavlovec et al. 1991); (iii) Lower Oligocene (NP21-22) calcareous turbidites in Budapest, Hungary, contain Upper Eocene (Priabonian) larger foraminifera: Chapmanina gassinensis and Nummulites fabianii (Varga 1982, 1985; Nagymarosy 1987); (iv) Lower Oligocene flysch in the Carpathians yielded Eocene Nummulites (Kulka 1985); (v) the Frazzanò Flysch of the Calabria-Peloritani arc previously dated by Upper Eocene foraminifera yielded Upper Oligocene calcareous nannofossils (de Capoa et al. 1997); (vi) similarly, flysch of the Sicilian Maghrebids containing Lower Oligocene planktonic foraminifera were dated by means of calcareous nannofossils to be at least Aquitanian (de Capoa et al. 2000); (vii) microfossils of Lower Miocene strata of the Zawada Formation in the Carpathians are dominated by reworked Middle Eocene planktonic foraminifera and calcareous nannoplankton (Oszczypko et al. 1999); and (viii) flysch of the Ionian Zone in the Hellenides, to the SE of the Outer Dinaride flysch basins, is Early Miocene in age and contains abundant reworked Cretaceous and Eocene nannofossils (Piper et al. 1978; Bellas 1997). Evidence for a considerable time gap between foraminifer and nannofossil ages arises also from our new results. For instance, isolated Lower to Middle Eocene Nummulites tests from various biozones occur together with older, massive Palaeogene and Cretaceous carbonate lithoclasts (Hagn et al. 1979) as well as with Middle to Upper Eocene planktonic foraminifera and Cretaceous to Palaeogene nannofossils from a number of biozones (Drobne et al. 1979) and with Upper Oligocene palynomorphs, nannofossils and larger foraminifera (Šparica et al. 2005) in the Pićan flysch profile on Istria. These strata have been dated herein to be not older than Late Burdigalian. Table 1 and Fig. 2 illustrate the contradiction of microfossil age data from the entire Outer Dinaride flysch. 


\section{Weak early-stage diagenesis}

Redeposition of micro- and macrofossils such as larger, smaller and planktonic foraminifera without intense signal of wearing or abrasion can be attributed to subaqueous mud volcanoes linked to dewatering, in what might be a dynamic, accretionary wedge-type environment (e.g. Kohl \& Roberts 1994). Probably, high water content of sediment prevented diagenesis initially, and allowed easy removal of carbonate particles from the siliciclastic matrix downslope of the submarine fans, over a longer time span. Such a mechanism for a continuous redeposition and accumulation of Eocene foraminifera until at least the Middle Miocene is very likely to have taken place in the imbricated frontal thrust belt of the Dinarides, interpreted as an accretionary wedge (Tari-Kovačić 1998).

\section{Implications for palaeogeography}

We have demonstrated that our new calcareous nannofossil data from the Outer Dinaride Cenozoic prove the presence of a wide range of Lower Cretaceous, Upper Cretaceous, Paleocene, several non-overlapping Eocene, Oligocene and Miocene species in these strata.

The significance of our results is twofold. On the one hand, they indicate that the Cretaceous platform carbonate nappes have been covered by pelitic sediments, connected with progressive sediment reworking during the Cenozoic. It is essential to assume that before, during, and after the deposition of the Eocene foraminiferal limestones in the present-day Outer Dinaride coastal range, there existed widespread marine environments, covering the Cretaceous platform carbonates in the inner imbricate belt, where the nannofossils can be derived from.

On the other hand, the data strongly suggest a considerably younger, at least Burdigalian sedimentation age throughout the onshore flysch deposits, with clear implications on Outer Dinaride tectonics. Overall, this picture is best explained by a series of wedge-top basins (see DeCelles \& Giles 1996) progressively migrating towards the Apulian foreland.

The flysch develops from the underlying 'Globigerina Marl' (Marjanac \& Ćosović 2000). These shelf to shallow bathyal deposits are dated by means of micro- and macrofauna and by calcareous nannofossils (Muldini-Mamužić 1965; Benić 1991; Drobne \& Pavlovec 1991; Pavšič \& Premec-Fuček 2000; Schweitzer et al. 2005) ranging in age from Paleocene in the NW to Upper Eocene in the SE.

Biostratigraphic results obtained in our study for Central Dalmatia and the Southern Adriatic Zone agree well with the findings of Puškarić (1987), Radoičić et al. (1989, 1991), de Capoa et al. (1995), and de Capoa \& Radoičić (1994a, b, 2002) who first demonstrated Neogene nannofossil age in a number of flysch localities of the SE part of the basin system. Further to the SE, flysch in the Ionian Zone in the Hellenides is likewise dated to be Lower Miocene (Piper et al. 1978; Bellas 1997). Our new data, however, lead us to extend the Miocene sedimentation ages to other portions of the coastal onshore localities as well, from Northern Dalmatia through Pag Island untill the Istrian Peninsula. As a consequence, proposing SE-directed diachroneity along the Outer Dinaride front (Piccoli \& Proto Decima 1969) is no longer reasonable. Furthermore, superposition of Neogene flysch onto the Eocene 'Marl with crabs' or Globigerina marl implies a widespread, basin-scale regional unconformity, but hitherto this issue has not received much attention. In fact, the thickness of the Globigerina marl varies extremely from 10 to $150 \mathrm{~m}$ (Marjanac $\&$ Ćosović 2000), and contacts with angular (Marjanac 2000) or erosional (Marjanac et al. 1998) unconformity to the overlying flysch both exist. Sikic (1963, 1968) also argued that deposition of both the units was interrupted by a deformational event and suggested the existence of a basin-wide unconformity. An abrupt change in the composition of the planktonic foraminifer fauna above a carbonate debrite horizon separating the Globigerina marl and the flysch was noted by Muldini-Mamužić (1965). De Capoa et al. (1995) noted that a hardground is developed on top of the 'Marl with crabs', directly overlain by flysch. All these data suggest a break in sedimentation and possibly slight submarine erosion as well, in spite of the classical view dealing with the progressive transition of the Globigerina marl to the flysch (see review in Marjanac \& Ćosović 2000). Although remnants of Palaeogene flysch can exist in the coastal range, our data clearly imply that, at most localities in the basin, the flysch is of Neogene age and separated from the Globigerina marl or from older flysch strata by unconformity (Fig. 5).

The heavy mineral composition of the flysch (Magdalenić 1972; Mikes et al. 2004, 2005) and especially the nannofossil 'age spectra' both exhibit a remarkable degree of basinwide homogenization. In the course of wedge-top deposition, a series of small, relatively shallow basins could have been developed on and in front of the advancing thrust sheets. The 'smoothing' is interpreted as a result of multiple reworking from the precursor flysch slices and sediment dispersal that occurred within the westwardpropagating, complex thrust wedge (Fig. 6).

\section{Implications for Cenozoic deformation history}

Flysch remnants are typically sandwiched between thrust sheets, and occur in different structural 


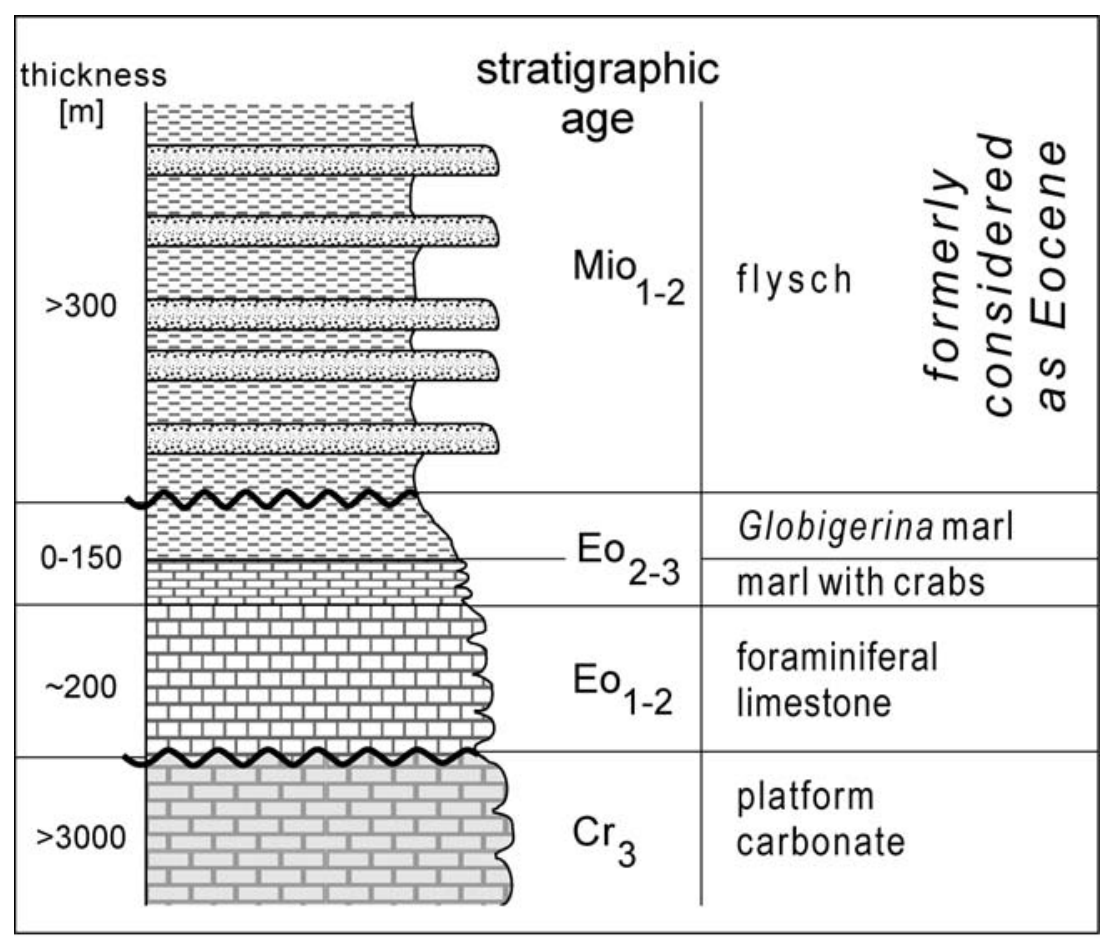

Fig. 5. Schematic stratigraphic setting of the Outer Dinaride flysch in the coastal range according to the new nannofossil age data. As it directly overlies well-dated Eocene Globigerina marls, their relationship requires the presence of a major, basin-wide unconformity separating them. At places however, small erosional remnants of older, Palaeogene flysch may also still exist in the same orogenic strike.

position in the Outer Dinaride nappe pile. The Bosnian Flysch is in uppermost position, and ranges in age up to Turonian to Paleocene (Dimitrijević 1997 p. 38, Hrvatović 1999; Christ 2007). Turbiditic sequences of comparable age are found in the same structural position along orogenic strike in isolated outcrops near Zagreb, Bosanski Novi and Bihać (Jelaska et al. 1969; Babić 1974; Babić \& Zupanič 1976; Crnjaković 1981) and in the Slovenian Trough (e.g. Buser 1987). These units are thrust on the AdCP, an imbricated pile of Mesozoic carbonates, the detachment surfaces being marked by a series of extremely narrow slices of Cenozoic flysch. Here, limited evidence suggests Early Eocene age of deposition (samples TD100 and TD109; planktonic foraminifer data of Krašeninnikov et al. 1968). In the thrust slices below, available biostratigraphic and sedimentological data suggest a foreland-directed migration of clastic facies zones in the Palaeogene (e.g. Bignot 1972; Engel 1974; Chorowicz 1977; Drobne 1977; Cadet 1978; Marinčić 1981; Košir 1997).

Our new biostratigraphic data imply postmid-Miocene deformation in the Outer Dinaride coastal range. Older thrusting events to the NE are recorded by the Lower and Upper Cretaceous units of the folded Bosnian Flysch (Dimitrijević 1997; Hrvatović 1999; Christ 2007; Petri 2007) and by Lower Eocene flysch slices thrust by Mesozoic carbonates (Krašeninnikov et al. 1968). On the other hand, to the SW of our sample sites, deformed Pliocene sediments and GPS measurements indicate ongoing shortening along the coastal range (TariKovačić 1998; Pribičević et al. 2002; Picha 2002; Tari 2002; Prelogović et al. 2003; Altiner et al. 2006; Mantovani et al. 2006; Vrabec \& Fodor 2006). Therefore, the new Miocene nannofossil depositional age of most flysch units and their structural position indicate that both sedimentation and deformation have been a long-lived continuous process in the Dinarides. The formation, subsidence and inversion of the sub-basins and thus sediment cannibalization are well-documented by the high proportion of recycled nannofossils.

\section{Conclusions}

Sixty-nine samples taken along the $700 \mathrm{~km}$ onshore sector of the Outer Dinaride flysch belt were analysed for calcareous nannofossils. Most of them yielded 


Adriatic offshore area coastal range imbricated carbonate platform BSM Jurassic-Cretaceous arc-trench complex
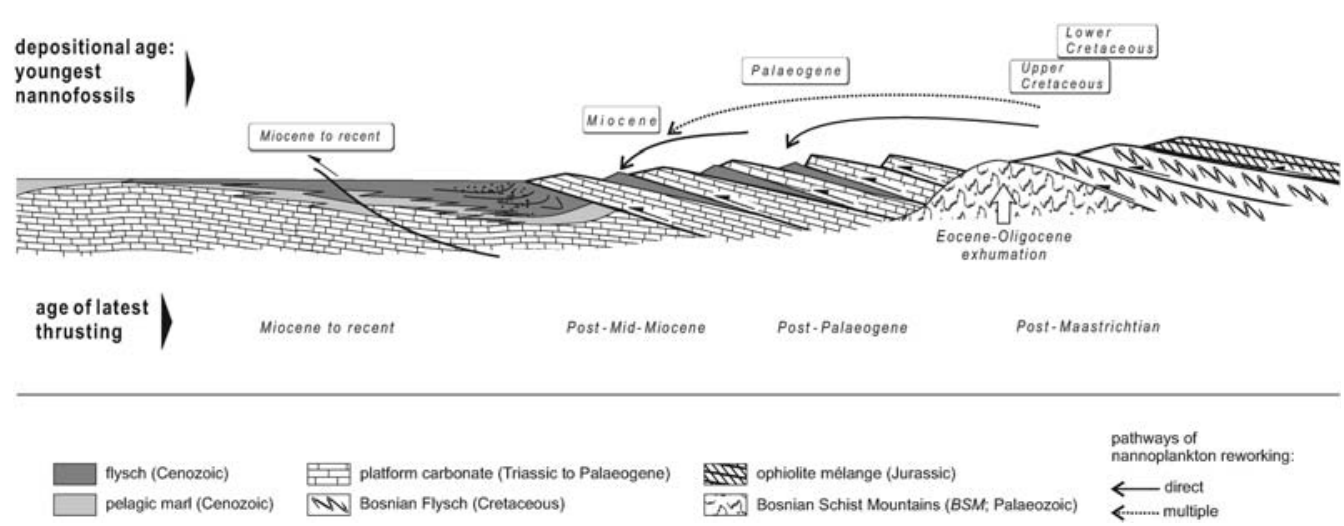

Fig. 6. Schematic sketch showing the implications of biostratigraphic data. With progressive nappe propagation towards Apulia, shallow foredeeps develop at the actual nappe front. Continuous thrusting and associated sediment off-scraping result in consecutive reworking of planktonic fossils into younger strata. Flysch remnants preserved at the base of thrust sheets become progressively younger towards Apulia. This process lasted until at least the late Early Miocene in the present-day Outer Dinaride coastal range, as indicated by deformed flysch sediments yielding Neogene calcareous nannoplankton. In the offshore Adriatic basin, clastic sedimentation has lasted until recent time. Age of the Bosnian Flysch taken from Hrvatović (1999) and Christ (2007). In the upper nappe unit of the Bosnian Flysch, an Albian deformation phase is also supposed (Petri 2007). Thermal history of the Bosnian Schist Mountains after Pamić et al. (2004).

mixed nannoflora with Cretaceous, Palaeogene and Neogene species. In the light of the new nannofossil data presented herein, we suggest that the flysch sedimentation lasted at least up to the MidMiocene all along the Dinaride coastal range. In spite of disagreement with existing planktonic foraminifer biostratigraphic data, our results are well in line with recently published nannofossil data from a number of localities within the flysch basin.

A majority of the nannoflora consists of Middle Eocene taxa, together with less abundant Cretaceous, Paleocene and Oligocene nannofossils. Wherever Neogene species have been discovered, all these older floras are implied to be recycled from older flysch units of the Outer Dinaride accretionary wedge. Cretaceous platform carbonate nappes of the Outer Dinarides were extensively covered by Cenozoic marine sediments. Remnants are preserved at the base of thrust sheets while the reworked microfossils also testify to the existence of Cenozoic basins on top of the accretionary wedge.

The stratigraphic relation of well-dated Eocene Globigerina marls lacking evidence for reworked fossil content and the Neogene flysch allows us to propose a working hypothesis on a major, widespread, hitherto largely ignored unconformity along the entire Dinaride coastal range, which requires further field evidence.

The Miocene onshore Outer Dinaride flysch suffered severe compressional deformation and is typically preserved below the imbricate thrust sheets of the Dinaride carbonate platform. Along the coastal zone, the deformation post-dates Middle Miocene. This compressional phase provides evidence for the continuity of deformational events between the more internal, older Late Cretaceous to Palaeogene compressional phases and the ongoing thrusting at the Adriatic front.

Our most sincere gratitude is due to a number of colleagues in the University of Zagreb for their invaluable and friendly help, especially to Lj. Babić, V. Ćosović and T. Marjanac. Essential local literature, maps and field discussions all formed a solid basis to perform this study. Substantial aid with field work in Montenegro was received from D. Čađenović (Podgorica). F. Rögl (Vienna) and V. Ćosović kindly offered their expertise on foraminifer biostratigraphy. Responsibility for the conclusions presented are borne by the authors alone. Constructive criticism by M. Wagreich (Vienna) and an anonymous reviewer significantly improved the manuscript. The work was supported by the Deutsche Forschungsgemeinschaft (DFG Ey 23/4). 


\section{Appendix A. List of all taxa cited in the text and figures}

Arkhangelskiella cymbiformis Vekshina 1959

Arkhangelskiella sp.

Blackites creber (Deflandre 1954) Roth 1970

Blackites sp.

Braarudosphaera bigelowi (Gran \& Braarud 1935) Deflandre 1947

Braarudosphaera sp.

Broinsonia sp.

Calcidiscus leptoporus (Murray \& Blackman 1898) Loeblich \& Tappan 1978

Calcidiscus macintyrei (Bukry \& Bramlette 1969) Loeblich \& Tappan 1978

Calcidiscus premacintyrei Theodoridis 1984

Calcidiscus tropicus Kamptner 1956 sensu Gartner 1992

Chiasmolithus grandis (Bramlette \& Riedel 1954) Radomski 1968

Chiasmolithus modestus Perch-Nielsen 1971

Chiasmolithus oamaruensis (Deflandre 1954) Hay, Mohler \& Wade 1966

Chiasmolithus solitus (Bramlette \& Sullivan 1961) Locker 1968

Chiasmolithus sp.

Chiastozygus sp.

Clausiococcus fenestratus (Deflandre \& Fert 1954) Prins 1979

Coccolithus eopelagicus (Bramlette \& Riedel, 1954) Bramlette \& Sullivan 1961

Coccolithus miopelagicus Bukry 1971

Coccolithus pelagicus (Wallich 1871) Schiller 1930

Coronocyclus nitescens (Kamptner 1963) Bramlette \& Wicoxon 1967

Cribrocentrum reticulatum (Gartner \& Smith 1967) Perch-Nielsen 1971

Cribrosphaerella ehrenbergii (Arkhangelsky 1912) Deflandre in Piveteau 1952

Cyclagelosphaera reinhardtii (Perch-Nielsen 1968) Romein 1977

Cyclicargolithus abisectus (Müller 1970) Wise 1973

Cyclicargolithus floridanus (Roth \& Hay in Hay et al. 1967) Bukry 1971

Cyclicargolithus luminis (Sullivan 1965) Bukry 1971

Cyclicargolithus sp.

Cyclococcolithus formosus Kamptner 1963

Discoaster aster Bramlette \& Riedel 1954

Discoaster barbadiensis Tan 1927

Discoaster binodosus Martini 1958

Discoaster deflandrei Bramlette \& Riedel 1954

Discoaster distinctus Martini 1958

Discoaster exilis Martini \& Bramlette 1963

Discoaster lenticularis Bramlette \& Sullivan 1961

Discoaster lodoensis Bramlette \& Riedel 1954

Discoaster mirus Deflandre in Deflandre \& Fert 1954

Discoaster multiradiatus Bramlette \& Riedel 1954

Discoaster nodifer (Bramlette \& Riedel, 1954) Bukry 1973

Discoaster saipanensis Bramlette \& Riedel 1954

Discoaster septemradiatus (Klumpp 1953) Martini 1958

Discoaster sublodoensis Bramlette \& Sullivan 1961

Discoaster tanii Bramlette \& Riedel 1954

Discoaster sp.

Discolithina multipora (Kamptner 1948) Martini, 1965

Discolithina plana (Bramlette \& Sullivan, 1961)

Perch-Nielsen 1971

Discolithina $\mathrm{sp}$.

Eiffellithus eximius (Sover 1966) Perch-Nielsen 1968
Campanian-Maastrichtian

Upper Cretaceous

Eocene

Cretaceous-recent

Albian-Maastrichtian

NN2-21

NN7-19

NN4-6

NN4-10

NP11-17

NP16

NP18-22

NP10-16

Palaeogene-NN1

Eocene

?NN5-8

Eocene-Recent

Eocene-Miocene

NP16-20

Albian-Maastrichtian

Cretaceous-Paleocene

NP24-NN1

Middle Eocene-NN7

Middle Eocene-Oligocene

Eocene-NP21

Miocene

NP10-20

Lower to Middle Eocene

Eocene-Oligocene

NP12-14

NN4-9

NP9-10

NP12-14

?NP13-14

NP9-11

NP15-22

NP15-20

NP12-14

NP14-15

NP16-22

Eocene-Miocene

?Palaeogene

Turonian-Campanian 


\section{Appendix A. Continued}

Eiffellithus sp.

Eiffellithus turriseiffelii (Deflandre in Deflandre \& Fert 1954) Reinhardt 1965

Helicosphaera ampliaperta Bramlette \& Wilcoxon 1967

Helicosphaera carteri (Wallich 1877) Kamptner 1954

Helicosphaera compacta Bramlette \& Wicoxon 1967

Helicosphaera euphratis Haq 1966

Helicosphaera intermedia Martini 1965

Helicosphaera obliqua Bramlette \& Wilcoxon 1967

Helicosphaera seminulum Bramlette \& Sullivan 1961

Heliolithus kleinpelli Sullivan 1964

Isthmolithus recurvus (Deflandre in Deflandre \& Fert 1954)

Lanternithus minutus Stradner 1962

Lophodolithus nascens Bramlette \& Sullivan 1961

Markalius inversus (Deflandre in Deflandre \& Fert 1954)

Bramlette \& Martini 1964

Marthasterites sp.

Micrantholithus vesper Deflandre 1954

Microrhabdulus sp.

Micula sp.

Nannoconus steinmanni Kamptner 1931

Nannotetrina sp.

Neococcolithes dubius (Deflandre in Deflandre \& Fert 1954) Black 1967

Pemma papillatum Martini 1959

Pemma rotundum Klumpp 1953

Pemma sp.

Reticulofenestra bisecta (Hay, Mohler \& Wade 1966) Roth 1970

Reticulofenestra haqii Backman 1978

Reticulofenestra lockeri Müller 1970

Reticulofenestra placomorpha (Kamptner 1948) Stradner in Stradner \& Edwards 1968 [actual valid synonym:

R. umbilica (Levin 1965) Martini \& Ritzkowski 1968)]

Reticulofenestra pseudoumbilicus (Gartner 1967) Gartner 1969

Rhabdolithus sp.

Sphenolithus conicus Bukry 1971

Sphenolithus furcatolithoides Locker 1967

Sphenolithus moriformis (Brönnimamm \& Stradner 1960) Bramlette \& Wilcoxon 1967

Sphenolithus radians Deflandre in Deflandre \& Fert 1954

Sphenolithus sp.

Sphenolithus sp. (?calyculus: Bukry 1985)

Sphenolithus spiniger Bukry 1971

Transversopontis pulcher (Deflandre in Deflandre \& Fert 1954) Hay, Mohler \& Wade 1966

Transversopontis sp.

Tribrachiatus orthostylus Shamrai 1963

Umbilicosphaera rotula (Kamptner 1956) Varol 1982

Uniplanarius gothicus (Deflandre 1959) Hattner \& Wise, 1980

Watznaueria barnesae (Black 1959) Perch-Nielsen 1968

Zeugrhabdotus embergeri (Noël 1958) Perch-Nielsen 1984

Zeugrhabdotus sp.

Zygrhablithus bijugatus (Deflandre in Deflandre \& Fert 1954) Deflandre 1959
Upper Albian-Maastrichtian

\section{NN2-4 \\ NN1-recent}

Middle Eocene-NP24

Middle Eocene-Miocene

Middle Eocene-Miocene

NP24-NN6

Lower-Middle Eocene

NP6-9

NP 20-22 (marker of base NP20;

Martini 1971)

NP16-22

NP9-15

Cretaceous-Eocene

Upper Cretaceous

Eocene-Miocene

Cenomanian-Maastrichtian

Coniacian-Maastrichtian

Uppermost Jurassic-Lower

Cretaceous

NP15

NP13-16 (?17-18)

Middle Eocene

Middle Eocene

Middle Eocene

NP16-25 (or NN1)

NN2-15

NP23 rare, NP24-?NN1

NP16-22

NN4-15 $(<7 \mu \mathrm{m}$ occurs from NN5 in the Mediterranean)

NP25-NN3

NP15-16

Lower Eocene-Miocene

Lower to Middle Eocene (rare in Upper Eocene)

S. calyculus: Palaeogene-NN1

Middle Eocene

Eocene-Oligocene

NP11-12 (?13-14)

NN2-16

Santonian-Maastrichtian

Bajocian-Masstrichtian

Tithonian-Maastrichtian

Eocene-NP25

Note: Stratigraphic ranges of species taken from the following sources. Cretaceous: Burnett (1998) and Perch-Nielsen (1985a); Palaeogene: Perch-Nielsen (1985b) and Báldi-Beke (1977, 1984); Neogene: Fornaciari et al. (1996), Fornaciari \& Rio (1996) and Young (1998). 
Appendix B. Geographic position of sampling localities

\begin{tabular}{|c|c|c|c|c|}
\hline Area & Sample & Locality & Latitude (N) & Longitude (E) \\
\hline \multirow[t]{14}{*}{ Istria } & TD11 & Dekani & $45^{\circ} 33^{\prime} 4.3^{\prime \prime}$ & $13^{\circ} 48^{\prime} 25.0^{\prime \prime}$ \\
\hline & TD13 & Izola & $45^{\circ} 31^{\prime} 58.5^{\prime \prime}$ & $13^{\circ} 38^{\prime} 24.2^{\prime \prime}$ \\
\hline & TD15 & Korte & $45^{\circ} 29^{\prime} 14.7^{\prime \prime}$ & $13^{\circ} 40^{\prime} 14.7^{\prime \prime}$ \\
\hline & TD16 & Babiči & $45^{\circ} 30^{\prime} 55.0^{\prime \prime}$ & $13^{\circ} 46^{\prime} 55.0^{\prime \prime}$ \\
\hline & TD18 & Korte & $45^{\circ} 29^{\prime} 35.3^{\prime \prime}$ & $13^{\circ} 40^{\prime} 35.3^{\prime \prime}$ \\
\hline & MOM-3 & Momjan & $45^{\circ} 26^{\prime} 3.2^{\prime \prime}$ & $13^{\circ} 42^{\prime} 18.5^{\prime \prime}$ \\
\hline & TD22 & Momjan & $45^{\circ} 25^{\prime} 8.0^{\prime \prime}$ & $13^{\circ} 42^{\prime} 8.0^{\prime \prime}$ \\
\hline & BNE-1 & Zrenj-Baredine & $45^{\circ} 25^{\prime} 14.6^{\prime \prime}$ & $13^{\circ} 53^{\prime} 32.3^{\prime \prime}$ \\
\hline & KSG-1 & Kaščerga & $45^{\circ} 18^{\prime} 38.9^{\prime \prime}$ & $13^{\circ} 54^{\prime} 46.2^{\prime \prime}$ \\
\hline & PIC-2 & Pićan & $45^{\circ} 12^{\prime} 16.2^{\prime \prime}$ & $14^{\circ} 2^{\prime} 46.2^{\prime \prime}$ \\
\hline & TD171 & Lukačići & $45^{\circ} 10^{\prime} 53.5^{\prime \prime}$ & $14^{\circ} 0^{\prime} 25.9^{\prime \prime}$ \\
\hline & TD173 & Škrbani & $45^{\circ} 10^{\prime} 17.8^{\prime \prime}$ & $14^{\circ} 0^{\prime} 54.7^{\prime \prime}$ \\
\hline & TD177 & Baštini near Draguć & $45^{\circ} 20^{\prime} 16.2^{\prime \prime}$ & $14^{\circ} 0^{\prime} 18.2^{\prime \prime}$ \\
\hline & TD178 & Baštini near Draguć & $45^{\circ} 20^{\prime} 16.2^{\prime \prime}$ & $14^{\circ} 0^{\prime} 18.2^{\prime \prime}$ \\
\hline Northern Kvarner: & TD28 & Draga Bašćanska & $44^{\circ} 59^{\prime} 34.0^{\prime \prime}$ & $14^{\circ} 43^{\prime} 0.7^{\prime \prime}$ \\
\hline \multirow[t]{2}{*}{$\begin{array}{l}\text { Krk Island }+ \text { nearby } \\
\text { mainland areas }\end{array}$} & TD29 & $\begin{array}{l}\text { Bribir (road crossing Grižane/ } \\
\text { Selce) }\end{array}$ & $45^{\circ} 13^{\prime} 8.8^{\prime \prime}$ & $14^{\circ} 41^{\prime} 31.1^{\prime \prime}$ \\
\hline & TD30 & Bribir (Stale) & $45^{\circ} 9^{\prime} 59.9^{\prime \prime}$ & $14^{\circ} 45^{\prime} 11.9^{\prime \prime}$ \\
\hline \multirow{3}{*}{$\begin{array}{l}\text { Northern Kvarner: } \\
\text { Rab Island }\end{array}$} & TD32 & $\mathrm{Rab}$ & $44^{\circ} 46^{\prime} 11.9^{\prime \prime}$ & $14^{\circ} 45^{\prime} 21.1^{\prime \prime}$ \\
\hline & TD35 & Lopar & $44^{\circ} 50^{\prime} 23.8^{\prime \prime}$ & $14^{\circ} 43^{\prime} 10.9^{\prime \prime}$ \\
\hline & TD37 & Dumići & $44^{\circ} 48^{\prime} 12.9^{\prime \prime}$ & $14^{\circ} 42^{\prime} 29.9^{\prime \prime}$ \\
\hline \multirow[t]{5}{*}{ Pag Island } & TD261 & Stara Vas, $10 \mathrm{~km} \mathrm{SE}$ of Pag town & $44^{\circ} 22^{\prime} 53.5^{\prime \prime}$ & $15^{\circ} 9^{\prime} 12.1^{\prime \prime}$ \\
\hline & TD262 & Stara Vas, $10 \mathrm{~km} \mathrm{SE}$ of Pag town & $44^{\circ} 22^{\prime} 53.5^{\prime \prime}$ & $15^{\circ} 9^{\prime} 12.1^{\prime \prime}$ \\
\hline & TD265 & Stara Vas, $10 \mathrm{~km} \mathrm{SE} \mathrm{of} \mathrm{Pag} \mathrm{town}$ & $44^{\circ} 22^{\prime} 51.2^{\prime \prime}$ & $15^{\circ} 9^{\prime} 8.0^{\prime \prime}$ \\
\hline & TD269 & $\begin{array}{l}\text { coastal cliffs at the SE tip of Pag } \\
\text { Island, near Vlašići }\end{array}$ & $44^{\circ} 19^{\prime} 5.1^{\prime \prime}$ & $15^{\circ} 13^{\prime} 39.7^{\prime \prime}$ \\
\hline & TD272 & $\begin{array}{l}\text { coastal cliffs at the SE tip of Pag } \\
\text { Island, near Vlašići }\end{array}$ & $44^{\circ} 19^{\prime} 4.8^{\prime \prime}$ & $15^{\circ} 13^{\prime} 38.8^{\prime \prime}$ \\
\hline \multirow{5}{*}{$\begin{array}{l}\text { Northern Dalmatia } \\
\text { (Ravni-Kotari) }\end{array}$} & TD251 & Šopot railway cut near Benkovac & $44^{\circ} 1^{\prime} 24.1^{\prime \prime}$ & $15^{\circ} 35^{\prime} 36.5^{\prime \prime}$ \\
\hline & TD253 & Šopot railway cut near Benkovac & $44^{\circ} 1^{\prime} 25.5^{\prime \prime}$ & $15^{\circ} 35^{\prime} 42.5^{\prime \prime}$ \\
\hline & TD255 & Šopot railway cut near Benkovac & $44^{\circ} 1^{\prime} 25.5^{\prime \prime}$ & $15^{\circ} 35^{\prime} 43.2^{\prime \prime}$ \\
\hline & TD257 & Šopot railway cut near Benkovac & $44^{\circ} 1^{\prime} 27.1^{\prime \prime}$ & $15^{\circ} 35^{\prime} 50.6^{\prime \prime}$ \\
\hline & TD260 & $\begin{array}{l}\text { Zagreb-Split motorway, } 3 \mathrm{~km} \\
\text { SSW of Islam Latinski exit }\end{array}$ & $44^{\circ} 10^{\prime} 21.2^{\prime \prime}$ & $15^{\circ} 25^{\prime} 33.5^{\prime \prime}$ \\
\hline \multirow[t]{15}{*}{ Central Dalmatia } & TD227 & $\begin{array}{l}\text { Mravince, } 200 \mathrm{~m} \mathrm{E} \text { of the } \\
\text { limestone olistolith }\end{array}$ & $43^{\circ} 32^{\prime} 9.3^{\prime \prime}$ & $16^{\circ} 30^{\prime} 41.5^{\prime \prime}$ \\
\hline & TD229 & Mravince, marl quarry & $43^{\circ} 32^{\prime} 16.0^{\prime \prime}$ & $16^{\circ} 31^{\prime} 3.9^{\prime \prime}$ \\
\hline & TD232 & $\begin{array}{l}\text { Mravince abandoned quarry near } \\
\text { police }\end{array}$ & $43^{\circ} 32^{\prime} 7.3^{\prime \prime}$ & $16^{\circ} 31^{\prime} 26.8^{\prime \prime}$ \\
\hline & TD233 & $\begin{array}{l}\text { Mravince abandoned quarry near } \\
\text { police }\end{array}$ & $43^{\circ} 32^{\prime} 3.6^{\prime \prime}$ & $16^{\circ} 31^{\prime} 23.0^{\prime \prime}$ \\
\hline & TD234 & $\begin{array}{l}\text { Mravince abandoned quarry near } \\
\text { police }\end{array}$ & $43^{\circ} 32^{\prime} 3.6^{\prime \prime}$ & $16^{\circ} 31^{\prime} 23.0^{\prime \prime}$ \\
\hline & TD236 & $\begin{array}{l}\text { Jadro creek right side, larger one } \\
\text { out of two quarries }\end{array}$ & $43^{\circ} 32^{\prime} 34.9^{\prime \prime}$ & $16^{\circ} 31^{\prime} 17.0^{\prime \prime}$ \\
\hline & TD240 & Jadro valley, Vrilo Jadro & $43^{\circ} 32^{\prime} 39.3^{\prime \prime}$ & $16^{\circ} 31^{\prime} 31.6^{\prime \prime}$ \\
\hline & TD246 & Gizdići near Klis & $43^{\circ} 33^{\prime} 27.1^{\prime \prime}$ & $16^{\circ} 30^{\prime} 14.5^{\prime \prime}$ \\
\hline & TD248 & Solin, Voljak Street & $43^{\circ} 33^{\prime} 14.9^{\prime \prime}$ & $16^{\circ} 29^{\prime} 26.6^{\prime \prime}$ \\
\hline & TD249 & Solin, Voljak Street & $43^{\circ} 33^{\prime} 14.9^{\prime \prime}$ & $16^{\circ} 29^{\prime} 26.6^{\prime \prime}$ \\
\hline & TD52 & Živogošće & $43^{\circ} 11^{\prime} 15.6^{\prime \prime}$ & $17^{\circ} 9^{\prime} 43.8^{\prime \prime}$ \\
\hline & TD55 & Omiš quarry, E wall & $43^{\circ} 25^{\prime} 33.8^{\prime \prime}$ & $16^{\circ} 42^{\prime} 53.0^{\prime \prime}$ \\
\hline & TD56 & Omiš quarry, E wall & $43^{\circ} 25^{\prime} 33.8^{\prime \prime}$ & $16^{\circ} 42^{\prime} 53.0^{\prime \prime}$ \\
\hline & TD53 & Medići near Omiš & $43^{\circ} 24^{\prime} 19.9^{\prime \prime}$ & $16^{\circ} 48^{\prime} 20.4^{\prime \prime}$ \\
\hline & TD54 & Mala Luka near Omiš & $43^{\circ} 25^{\prime} 10.0^{\prime \prime}$ & $16^{\circ} 42^{\prime} 59.6^{\prime \prime}$ \\
\hline
\end{tabular}


Appendix B. Continued

\begin{tabular}{|c|c|c|c|c|}
\hline \multirow[t]{3}{*}{ Dalm.-Herz. Zone } & TD100 & Spuž & $42^{\circ} 31^{\prime} 31.3^{\prime \prime}$ & $19^{\circ} 11^{\prime} 2.0^{\prime \prime}$ \\
\hline & TD109 & Medun & $42^{\circ} 28^{\prime} 16.1^{\prime \prime}$ & $19^{\circ} 21^{\prime} 51.7^{\prime \prime}$ \\
\hline & TD140 & Crnići & $43^{\circ} 7^{\prime} 34.1^{\prime \prime}$ & $17^{\circ} 51^{\prime} 32.3^{\prime \prime}$ \\
\hline \multirow[t]{17}{*}{ S-Adriatic Zone } & TD51 & Konavle hills & $42^{\circ} 33^{\prime} 44.9^{\prime \prime}$ & $18^{\circ} 18^{\prime} 28.5^{\prime \prime}$ \\
\hline & TD47 & Dubravka & $42^{\circ} 31^{\prime} 1.4^{\prime \prime}$ & $18^{\circ} 25^{\prime} 17.1^{\prime \prime}$ \\
\hline & TD49 & Dubravka & $42^{\circ} 31^{\prime} 57.8^{\prime \prime}$ & $18^{\circ} 24^{\prime} 56.9^{\prime \prime}$ \\
\hline & TD38 & Sutorina & $42^{\circ} 28^{\prime} 34.1^{\prime \prime}$ & $18^{\circ} 28^{\prime} 45.2^{\prime \prime}$ \\
\hline & TD136 & Sutorina & $42^{\circ} 28^{\prime} 20.0^{\prime \prime}$ & $18^{\circ} 25^{\prime} 36.9^{\prime \prime}$ \\
\hline & TD138 & Sutorina & $42^{\circ} 28^{\prime} 20.0^{\prime \prime}$ & $18^{\circ} 25^{\prime} 36.9^{\prime \prime}$ \\
\hline & TD39 & Tivat & $42^{\circ} 24^{\prime} 54.6^{\prime \prime}$ & $18^{\circ} 43^{\prime} 6.6^{\prime \prime}$ \\
\hline & TD127 & Radanovići & $42^{\circ} 20^{\prime} 45.3^{\prime \prime}$ & $18^{\circ} 30^{\prime} 37.9^{\prime \prime}$ \\
\hline & TD134 & Radanovići & $42^{\circ} 20^{\prime} 50.1^{\prime \prime}$ & $18^{\circ} 30^{\prime} 43.7^{\prime \prime}$ \\
\hline & TD99 & Stari Bar & $42^{\circ} 5^{\prime} 19.5^{\prime \prime}$ & $19^{\circ} 8^{\prime} 34.3^{\prime \prime}$ \\
\hline & TD43 & Zaljevo & $42^{\circ} 4^{\prime} 23.0^{\prime \prime}$ & $19^{\circ} 7^{\prime} 58.7^{\prime \prime}$ \\
\hline & TD116 & Ulcinj & $41^{\circ} 40^{\prime} 51.4^{\prime \prime}$ & $19^{\circ} 0^{\prime} 52.0^{\prime \prime}$ \\
\hline & TD120 & Donja Klezna - Gornja Klezna & $41^{\circ} 40^{\prime} 46.3^{\prime \prime}$ & $19^{\circ} 0^{\prime} 19.6^{\prime \prime}$ \\
\hline & TD123 & Donja Klezna - Gornja Klezna & $41^{\circ} 40^{\prime} 46.3^{\prime \prime}$ & $19^{\circ} 0^{\prime} 19.6^{\prime \prime}$ \\
\hline & TD125 & Donja Klezna - Gornja Klezna & $41^{\circ} 40^{\prime} 42.2^{\prime \prime}$ & $19^{\circ} 0^{\prime} 18.8^{\prime \prime}$ \\
\hline & TD93 & Kravari & $42^{\circ} 3^{\prime} 51.9^{\prime \prime}$ & $19^{\circ} 21^{\prime} 34.4^{\prime \prime}$ \\
\hline & TD45 & Vladimir & $42^{\circ} 0^{\prime} 39.1^{\prime \prime}$ & $19^{\circ} 17^{\prime} 15.8^{\prime \prime}$ \\
\hline
\end{tabular}

\section{References}

Altiner, Y., Marjanović, M., Medved, M. \& Rasić, L. 2006. Active deformation of the Northern Adriatic region: Results from the CRODYN geodynamical experiment. In: PINTER, N., GRENERCZY, G., Weber, J., Stein, S. \& Medak, D. (eds) The Adria Microplate: GPS Geodesy, Tectonics and Hazards. NATO Science Series IV, 61, Springer, 257-269.

BABIĆ, LJ. 1974. Hauterivian to Cenomanian time in the region of Žumberak, Northwestern Croatia: stratigraphy, sediments, paleogeographic and paleotectonic evolution. Geološki vjsenik, 27, 11-33.

BABIĆ, LJ. \& ZUPANIČ, J. 1976. Sediments and paleogeography of the Globotruncana calcarata Zone (Upper Cretaceous) in Banija and Kordun, central Croatia. Geološki vjsenik, 29, 49-74.

BABIĆ, LJ. \& ZUPANIČ, J. 1983. Palaeogene clastic formations in Northern Dalmatia: Excursion A2. In: BABIĆ, LJ. \& JelaskA, V. (eds) Contributions to sedimentology of some carbonate and clastic units of the coastal Dinarides. Excursion Guidebook, 4th IAS Regional Meeting, Split 1983. Zagreb.

BABIĆ, LJ. \& ZupANiČ, J. 1996. Coastal Dinaric flysch belt: paleotransport model for the Pazin Basin, and the role of a foreland uplift (Istria, Croatia). Natura Croatica, 5, 317-327.

BABIĆ, LJ. \& ZUPANIČ, J. 1998. Nearshore deposits in the Middle Eocene clastic succession in Northern Dalmatia (Dinarides, Croatia). Geologia Croatica, 51, 175-193.

BABIĆ, LJ., Zupanič, J. \& CRNJAKović, M. 1993. An association of marine tractive and gravity flow sandy deposits in the Eocene of the Island of Pag (Outer Dinarides, Croatia). Geologia Croatica, 46, 107-123.
BABIĆ, LJ., ZupAnič, J. \& JURAČIĆ, M. 1995. Supply from an Outer Carbonate Platform to the Foreland Basin of the Coastal Dinarides: the Pazin Flysch Basin (Eocene, Croatia). 1. Hrvatski geološki kongres Opatija, 1, 43-45.

BÁLDI-BEKE, M. 1977. Stratigraphical and faciological subdivisions of the Oligocene as based on nannoplankton. Földtani Közlöny, 107, 59-89.

BÁLDI-BEKE, M. 1984. The nannoplankton of the Transdanubian Palaeogene formations. Geologica Hungarica, Series Palaeontologica, 43.

BÁldi-BEKE, M. \& BÁLDI, T. 1991. Palaeobathymetry and palaeogeography of the Bakony Eocene Basin in western Hungary. Palaeogeography, Palaeoclimatology, Palaeoecology, 88, 25-52.

Bellas, S. M. 1997. Calcareous nannofossils of the Tertiary Flysch (Post Eocene to Early Miocene) of the Ionian Zone in Epirus, NW-Greece: Taxonomy and biostratigraphical correlations. Berliner Geowissenschaftliche Abhandlungen, $\mathbf{E}(\mathbf{2 2})$, $1-173$.

BENIĆ, J. 1975. Calcareous nannoplankton from the Eocene flysch on Pag Island. Geološki vjesnik, 28, 19-23.

BENIĆ, J. 1991. The age of the Istria flysch deposits based on calcareous nannofossils. In: Introduction to the Paleogene SW Slovenia and Istria Field-Trip Guidebook IGCP Project 286 'Early Paleogene Benthos', 2nd Meeting, Postojna.

BERGANT, S., TIŠLJAR, J. \& ŠPARICA, M. 2003. Istrian flysch and its relationship with flysch from NE Italy, SW Slovenia and the Adriatic coastal region in Croatia (Ravni Kotari area and Dalmatia). In: Evolution of Depositional Environments from the Palaeozoic to the Quaternary in the Karst Dinarides and 
the Pannonian Basin. 22nd IAS Meeting of Sedimentology, Opatija-Sept. 17-19, 2003, Field Trip Guidebook.

Bignot, G. 1972. Recherches stratigraphiques sur les calcaires du Crétacé supérieur et de ÍEocéne d'Istrie et des régions voisines. Essai de révision du Liburnien. Travaux du Laboratoire de Micropaléontologie, 2, 1-353.

Bown, P. R. \& Young, J. R. 1997. Mesozoic calcareous nannoplankton classification. Journal of Nannoplankton Research, 19, 21-36.

Bown, P. R. \& Young, J. R. 1998. Techniques. In: Bown, P. R. (ed.) Calcareous Nannofossil Biostratigraphy. Chapman \& Hall, London.

BurnetT, J. A. 1998. Upper Cretaceous. In: Bown, P. R. (ed.) Calcareous Nannofossil Biostratigraphy. Chapman \& Hall, London, 132-199.

BUSER, S. 1987. Development of the Dinaric and the Julian carbonate platforms and of the intermediate Slovenian basin (NW Yugoslavia). Memorie della Società Geologica Italiana, 40, 313-320.

CAdet, J. P. 1978. Essai sur l'évolution alpine d'une paléomarge continentale. Mémoires de la Société géologique de France, 57, 1-83.

ČAnOVić, M. \& DžodžO-Tomić, R. 1958. Vorläufige Mitteilung Über die Oligozäne Mikrofauna aus der Bohrung Us-6 bei Ulcinj (Montenegro). Geološki Glasnik (Titograd), 2, 203-213.

Channell, J. E. T., D’Argenio, B. \& Horváth, F. 1979. Adria, the African Promontory, in Mesozoic Mediterranean Palaeogeography. Earth Science Reviews, 15, 213-292.

Chorowicz, J. 1977. Étude géologique des Dinarides le long da la structure transversale Split-Karlovac (Yougoslavie). Publications de la Société Géologique du Nord, 1, 1-331.

Christ, M. D. 2007. Sedimentologie und Liefergebietsanalyse an ausgewählten Profilen des Bosnischen Flysches. M.Sc. Thesis, University of Göttingen, 89pp. + Appendix.

CRNJAKOVIĆ, M. 1981. Maastrichtian flysch sediments in the south-west part of Mt. Medvednica. Geološki vjsenik, 34, 47-61.

Ćosović, V., Drobne, K. \& Moro, A. 2004. Paleoenvironmental model for Eocene foraminiferal limestones of the Adriatic carbonate platform (Istrian Peninsula). Facies, 50, 61-75.

Ćosović, V., Marjanac, T., Drobne, K. \& Moro, A In press. Eastern Adriatic Coast - External Dinarids. In: MCCAnn, T. (ed.) Geology of Central Europe. Geological Society London, Special Publications.

CURRY, D. 1982. Differential preservation of foraminiferids in the English Upper Cretaceous - consequential observations. In: BANNER, F. T. \& LORD, A. R. (eds) Aspects of Micropalaeontology. Papers presented to Professor Tom Barnard. George Allen \& Unwin, London.

de Capoa, P., Guerrera, F., Perrone, V. \& SERrano, F. 1997. New biostratigraphic data on the Frazzanò Formation (Longi-Taormina Unit): consequences on defining the deformation age of the Calabria-Peloritani arc southern sector. Rivista Italiana di Paleontologia e Stratigrafia, 103, $343-356$.
DE CAPOA, P. \& RADOIČIĆ, R. 1994a. Calcareous nannoplankton biostratigraphy of Tertiary sequences of the Cukali-Budva Basin (Montenegro, External Dinarides, Yugoslavia). Rivista Española de Micropaleontologia, 26, 101-116.

DE CAPOA, P. \& RAdoičIć, R. 1994b. Tertiary nannoplankton biostratigraphy of the Zeta Intraplatform Furrow (Montenegro). Palaeopelagos, 4, 289-294.

DE CAPOA, P. \& RadoičIĆ, R. 2002. Geological implications of biostratigraphic studies in the external and internal domains of the Central-Southern Dinarides. Memorie della Società Geologica Italiana, $\mathbf{5 7}$, $185-191$.

de Capoa, P., Radoičić, R. \& D’Argenio, B. 1995. Late Miocene deformation of the External Dinarides (Montenegro and Dalmatia): New biostratigraphic evidence. Memorie di Scienze Geologiche, 47, 157-172.

De Capoa, P., Guerrera, F., Perrone, V., Serrano, F. \& Tramontana, M. 2000. The onset of the syn-orogenic sedimentation in the flysch basin of the Sicilian Maghrebids; state of the art and new biostratigraphic constraints. Eclogae Geologicae Helvetiae, 93, 65-79.

DeCelles, P. G. \& Giles, K. A. 1996. Foreland basin systems. Basin Research, 8, 105-123.

DE KAenel, E. \& Villa, G. 1996. Oligocene-Miocene calcareous nannofossil biostratigraphy and paleoecology from the Iberia abyssal plain. Proceedings of the Ocean Drilling Program, Scientific Results, 149, 79-145.

DimitriJeVić, M. D. 1997. Geology of Yugoslavia. Geological Institute GEMINI, Belgrade, 187pp.

Drobne, K. 1977. Alvéolines paléogènes de la Slovénie et de l'Istrie. Schweizerische Paläontologische Abhandlungen, 99.

Drobne, K. \& Pavlovec, R. 1991. Paleocene and Eocene beds in Slovenia and Istria. In: Introduction to the Paleogene SW Slovenia and Istria FieldTrip Guidebook IGCP Project 286 'Early Paleogene Benthos', 2nd Meeting, Postojna.

Drobne, K., PAVlovec, R., ŠIKIĆ, L. \& BENIĆ, J. 1979. Pićan, Istria - Cuisian, Lutetian. In: DrobNe, K. (ed.) 16th European Micropaleontological Colloquium, Guidebook. Ljubljana, F177-F182.

Einsele, G. 1992. Sedimentary Basins. Springer, Berlin.

ENGEL, W. 1974. Sedimentologische Untersuchungen im Flysch des Beckens von Ajdovščina (Slowenien). Göttinger Arbeiten zur Geologie und Paläontologie, 16, 1-65.

Federal Geological Institute (F.G.I.) 1970. SFR Yugoslavia Geological Map 1:500 000. Belgrade.

Fornaciari, E. \& Rio, D. 1996. Latest Oligocene to early middle Miocene quantitative calcareous nannofossil biostratigraphy in the Mediterranean region. Micropaleontology, 42, 1-36.

Fornaciari, E., Di Stefano, A., Rio, D. \& Negri, A. 1996. Middle Miocene quantitative calcareous nannofossil biostratigraphy in the Mediterranean region. Micropaleontology, 42, 37-63.

Grubić, A. \& Komatina, M. 1963. Properties of the Eocene-Oligocene Flysch between Split and Makarska. Sedimentologija, 2-3, 21-38.

Hagn, R., PAVlovec, R. \& PAVŠIČ, J. 1979. Gračišće near Pićan, Istria - Eocene. In: DrobNe, K. (ed.) 
16th European Micropaleontological Colloquium, Guidebook. Ljubljana.

HAYNES, J. R. 1981. Foraminifera. Macmillan, London. HerAK, M., MARINČIĆ, S. \& POLŠAK, A. 1976. Geology of the Island of Hvar. Prirodoslovna Istraživanja, 42, $5-14$.

HrVatović, H. 1999. Geološki vodić kroz Bosnu $i$ Hercegovinu. Zavod za Geologiju, Sarajevo.

Jelaska, V., AmŠEl, V., KAPOVIĆ, B. \& VuKsanović, B. 1969. Sedimentological characteristics of the clastic Upper Cretaceous of the western part of Bosanska Krajina. Nafta, 20, 487-495.

Jerković, L. \& MARTINI, E. 1976. Upper Eocene calcareous nannoplankton from Split and Dugi Rat (Yugoslavia). Nafta, 27, 67-70.

JURAČIĆ, M. 1979. Sedimentation depth of the 'Marls with crabs' based on planktonic to benthic foraminifer ratio. Geološki vjesnik, 31, 61-67.

Kohl, B. \& RoberTs, H. H. 1994. Fossil Foraminifera from four active mud volcanoes in the Gulf of Mexico. Geo-Marine Letters, 14, 126-134.

KOŠIR, A. 1997. Eocene platform-to-basin depositional sequence, southwestern Slovenia. Gaea heidelbergensis, 3, 205.

KRAŠENINNIKOV, V., MULDINI-MAMUŽIĆ, S. \& DŽodŽo-Tomić, R. 1968. Signification des foraminifères planctoniques pour la division du paléogène de la Yougoslavie et comparaison avec les autres régions examinées. Geološki vjesnik, 21, 117-145.

KulKa, A. 1985. Nummulites from Poręba near Myślenice (Polish Western Carpathians). Kwartalnik Geologiczny, 29, 199-236.

Luković, M. \& PetKović, K. 1952. Geology and tectonics of the area of Ulcinj (littoral of Montenegro); an analysis of previous works and some new contributions. SANU Posebna izdanja, knjiga 197, 4, 1-62.

MAGDALENIĆ, Z. 1972. Sedimentology of Central Istria flysch deposits. Prirodoslovna Istraživanja, 39, 1-34.

Mantovani, E., Babbucci, D., Viti, M., Albarello, D., Mugnaioli, E., Cenni, N. \& Casula, G. 2006. Post-Late Miocene kinematics of the Adria microplate: Inferences from geological, geophysical and geodetic data. In: Pinter, N., Grenerczy, G., Weber, J., Stein, S. \& Medak, D. (eds) The Adria Microplate: GPS Geodesy, Tectonics and Hazards. NATO Science Series IV, 61, Springer, 51-69.

MARINČIĆ, S. 1981. Eocene flysch of the Adriatic area. Geološki vjesnik, 34, 27-38.

MARJANAC, T. 1990. Reflected sediment gravity flows and their deposits in flysch of middle Dalmatia, Yugoslavia. Sedimentology, 37, 921-929.

MARJANAC, T. 1996. Deposition of megabeds (megaturbidites) and sea-level change in a proximal part of the Eocene-Miocene Flysch of central Dalmatia (Croatia). Geology, 24, 543-546.

MARJAnAC, T. 2000. Kaštela-Split flysch region. Vijesti Hrvatskoga geološkog društva, 37, 109-116.

Marjanac, T. \& Ćosović, V. 2000. Tertiary depositional history of Eastern Adriatic realm. Vijesti Hrvatskoga geološkog društva, 37, 93-103.

MARJANAC, T. \& MARJANAC, LJ. 1991. Shallow-marine clastic Paleogene on the Island of Rab (Northern Adriatic). In: Bosellini, A., BRANDNER, R., FlüGel, E., Purser, B., Schlager, W., Tucker, M. \&
ZENGER, D. (eds) Dolomieu Conference on Carbonate Platforms and Dolomitization, Ortisei, 159-160.

Marjanac, T., Babac, D., Benić, J. et al. 1998. Eocene carbonate sediments and sea-level changes on the NE part of Adriatic Carbonate Platform (Island of Hvar and Pelješac Peninsula, Croatia). Dela-Opera SAZU 4. razreda, 34, 243-254.

MARTINI, E. 1971. Standard Tertiary and Quaternary calcareous nannoplankton zonation. In: FARINACCI, A. (ed.) Proceedings of the Second Planktonic Conference, Roma 1970, 739-785.

Mikes, T., DunkL, I. \& Frisch, W. 2004. Provenance mixing in a foreland basin as revealed by sandstone geochemistry and detrital zircon fission track analysis: the Eocene flysch of the NW Dinarides. In: PENA Dos Reis, R., Callapez, P. \& Dinis, P. (eds) 23rd IAS Meeting of Sedimentology, Coimbra-Sept. 15-17, 2004, Abstracts Book, Coimbra.

Mikes, T., Dunkl, I. \& von Eynatten, H. 2005. Significance of ophiolitic detritus in the Tertiary External Dinaride flysch belt. Schriftenreihe der Deutschen Gesellschaft für Geowissenschaften, 38, 110-111.

Mindszenty, A., D’Argenio, B. \& Aiello, G. 1995. Lithospheric bulges recorded by regional unconformities. The case of Mesozoic-Tertiary Apulia. Tectonophysics, 252, 137-161.

MrINJEK, E. 1993. Sedimentology and depositional setting of alluvial Promina Beds in northern Dalmatia, Croatia. Geologia Croatica, 46, 243-261.

Muldini-MamuŽIĆ, S. 1962. Mikrofaunistische untersuchungen des Eozän-Flysches der Insel Rab. Geološki vjesnik, 15, 149-159.

Muldini-MamuŽIĆ, S. 1965. The microfauna of limestones and of the clastic development in the Paleogene of central Istria. Geološki vjesnik, 18, 281-289.

Nagymarosy, A. 1987. Geological key profile of Hungary. Buda Hills, Budapest, Róka-hegy, Ibolya Street, quarry. Tard Clay Formation. Hungarian Geological Institute, Budapest.

NAgymarosy, A. \& BÁLDI-BeKe, M. 1993. The Szolnok Unit and its probable paleogeographic position. Tectonophysics, 226, 457-470.

OLSZEWSKA, B. \& GARECKA, M. 1996. Foraminifer and nannoplankton biostratigraphy of the lower Miocene of the Carpathian Foredeep. Przeglad Geologiczny, 44, 1049-1053.

OREHEK, S. 1991. Palaeotransport of SW Slovenian flysch. In: Introduction to the Paleogene SW Slovenia and Istria Field-Trip Guidebook IGCP Project 286 'Early Paleogene Benthos', 2nd Meeting, Postojna, 27-31.

OSZCZYPKo, N., ANDREYEVA-GRIGOROVICH, A. S., Malata, E. \& OszCZypKo-Clowes, M. A. 1999. The lower Miocene deposits of the Rača Subunit near Nowy Sạcz (Maguma Nappe, Polish Outer Carpathians. Geological Carpathica, 50, 419-433.

Pamić, J., Balogh, K., Hrvatović, H., Balen, D., JURKović, I. \& PALINKAŠ, L. 2004. K-Ar and Ar-Ar dating of the Palaeozoic metamorphic complex from the Mid-Bosnian Schist Mts., Central Dinarides, Bosnia and Hercegovina. Mineralogy and Petrology, 82, 65-79.

PAMIĆ, J., GuŠIĆ, I. \& JelaskA, V. 1998. Geodynamic evolution of the Central Dinarides. Tectonophysics, 297, 251-268. 
PAvić, A. 1970. Paléogène marin du Montenegro. PhD. Thesis. Zavod za geološka Istraživanja Crne Gore. Titograd, 208pp.

PAVLOVEC, R. 2003. The type of nummulitins localities in the Dinarides. Materials and Geoenvironment, 50, $777-788$.

PAVlovec, R. 2006. Lower Eocene Nummulits from Trnovo in surroundings of Ilirska Bistrica (SW Slovenia). Geologija, 49, 45-52.

Pavlovec, R., Knez, M., Drobne, K. \& PavšIČ, J. 1991. Profiles: Košana, Sv. Trojica and Leskovec; the disintegration of the carbonate platform. In: Introduction to the Paleogene SW Slovenia and Istria FieldTrip Guidebook IGCP Project 286 'Early Paleogene Benthos', 2nd Meeting, 69-72.

PAVŠIČ, J. 1981. Nannoplankton of the flysch in the Slovenian coast. Radovi Znanstvenog Savjeta za Naftu, Sekcija za Primjenu Geologije, Geofizike i Geokemije, JAZU, Serija A., 8, 257-266.

PAVŠIČ, J. \& PECKMANN, J. 1996. Stratigraphy and sedimentology of the Piran Flysch Area (Slovenia). Annales (Annals for Istrian and Mediterranean Studies), 9, 123-138.

PAVŠIČ, J. \& PREMEC-FuČEK, V. 2000. Calcareous nannoplankton and planktonic foraminiferal Zones during the Middle and Upper Eocene of the Transitional Beds on the Adriatic platform. Annali del Museo Civico di Storia Naturale di Ferrara, 3, 22-23.

PERCH-NIELSEN, K. 1985a. Mesozoic calcareous nannofossils. In: Bolli, H. M., SAUnders, I. B. \& PERCHNielsen, K. (eds) Plankton stratigraphy. Cambridge University Press, Cambridge, 329-426.

PerCh-Nielsen, K. 1985b. Cenozoic calcareous nannofossils. In: Bolli, H. M., SAunders, I. B. \& PerCHNielsen, K. (eds) Plankton stratigraphy. Cambridge University Press, Cambridge, 427-554.

PETRI, R. 2007. Grad und Alter der schwachmetamorphen Überprägung an ausgewählten Profilen des Bosnischen Flysches. MSc. Thesis, University of Göttingen, 111pp. + Appendix.

Piccoli, G. \& Proto Decima, F. 1969. Ricerche biostratigrafiche sui depositi flyschoidi della regione Adriatica settentrionale e orientale. Memorie degli Instituti di Geologia e Mineralogia dell' Università di Padova, 27, 3-21.

PICHA, F. J. 2002. Late orogenic strike-slip faulting and escape tectonics in frontal Dinarides-Hellenides, Croatia, Yugoslavia, Albania and Greece. $A A P G$ Bulletin, 86, 1659-1671.

Piper, D. J. W., Panagos, A. G. \& Pe, G. G. 1978. Conglomeratic Miocene flysch of Western Greece. Journal of Sedimentary Petrology, 48, 117-126.

Pomerol, C. 1985. La transition Eocène-Oligocène: est-elle un phénomène progressif ou brutal? Bulletin de la Société géologique de France, série 8, $\mathbf{1}$, 263-267.

Postma, G., Babić, Lu., Zupanić, J. \& Røe, S.-L. 1988. Delta-front failure and associated bottomset deformation in a marine, gravelly Gilbert-type fan delta. In: Nemec, W. \& Steel, R. J. (eds) Fan deltas; sedimentology and tectonic settings. Blackie and Son, Glasgow, 91-102.

Prelogović, E., Pribičević, B., IVković, Ž., Dragičević, I., Buljan, R. \& Tomljenović, B.
2003. Recent structural fabric of the Dinarides and tectonically active zones important for petroleum-geological exploration in Croatia. Nafta, 55, 155-161.

Pribičević, B., Medak, D. \& Prelogović, E. 2002. Determination of the recent structural fabric in the Alps-Dinarides area by combination of geodetic and geologic methods. Raziskave s področja geodezije in geofizike, Zbornik predavanja, 2002, 57-64.

PUŠKARIĆ, S. 1987. Calcareous nannoplankton from clastic sediments of the Island of Hvar. RAD Jugoslavenske akademije znanosti $i$ umjetnosti, 431, 7-16.

RADOIČIĆ, R., DE CAPOA, P. \& D’ARGENIO, B. 1989. Late rather than early Tertiary deformation of External Dinarides. Stratigraphic evidence from Montenegro. Rendiconto dell' Accademia delle Scienze Fisiche e Matematiche Napoli, 56, 41-59.

RADOIČIĆ, R., DE CAPOA, P. \& D'ARGENIO, B. 1991. Middle-Late Miocenic age of the preorogenic sedimentation in the Dinaric carbonate platform domain of Herzegovina. Annales Géologiques de la Péninsule Balkanique, 55, 1-21.

Schmid, S. M., Fügenschuh, B., Matenco, L., SChuster, R., Tischler, M. \& Ustaszewski, K 2006. The Alps-Carpathians-Dinarides-connection: a compilation of tectonic units. In: SUDAR, M., ERCEGOVAC, M. \& GRUBić, A. (eds) XVIII Congress of the Carpathian-Balkan Geological Association, Belgrade.

SCHUBERT, R. J. 1905. Zur Stratigraphie des istrischnorddalmatinischen Mitteleocäns. Jahrbuch der Kaiserlich-Königlichen Geologischen Reichsanstalt, 55, 153-188.

Schulz, H.-M., Bechtel, A. \& SAChsenhofer, R. F. 2005. The birth of the Paratethys during the Early Oligocene: From Tethys to an ancient Black Sea analogue? Global and Planetary Change, 49, $163-176$.

Schweitzer, C. E., Ćosović, V. \& Feldmann, R. M. 2005. Harpactocarcinus from the Eocene of Istria, Croatia, and the paleoecology of the Zanthopsidae Via, 1959 (Crustacea: Decapoda: Brachyura). Journal of Paleontology, 79, 663-669.

Skaberne, D. 1987. Megaturbidites in the Paleogene flysch in the region of Anhovo (W. Slovenia, Yugoslavia). Memorie della Società Geologica Italiana, $\mathbf{4 0 ,}$ 231-239.

ŠIKIĆ, D. 1963. Eine vergleichende Darstellung der Entwicklung des jüngeren klastischen Paläogens in Istrien, dem kroatischen Küstenland und Dalmatien. Geološki vjesnik, 15, 329-336.

ŠIKIĆ, D. 1968. The development of the Paleogene and the Lutetian movements in northern Dalmatia. Geološki vjesnik, 22, 309-331.

ŠPARICA, M., KOCH, G., IBRAhIMPAŠIĆ, H., Galović, I. \& Bergant, S. 2005. New data to the Palaeogene stratigraphy of the clasticcarbonate beds in SE Istria, Croatia. In: Velić, I., Vlahović, I. \& Biondić, R. (eds) Third Croatian Geological Congress. Abstracts Book, Opatija, 29.09-01.10.2005, Zagreb.

STRADNER, H. 1962. Über das fossile Nannoplankton des Eozän-Flysch von Istrien. Verhandlungen der Geologischen Bundesanstalt, Jg. 1962, 176-186. 
TARI, V. 2002. Evolution of the northern and western Dinarides: a tectonostratigraphic approach. EGU Stephan Mueller Special Publication Series, 1, 1-21.

TARI-KovaČIĆ, V. 1998. Geodynamics of the Middle Adriatic offshore area, Croatia, based on stratigraphic and seismic analysis of Paleogene beds. Acta Geologica Hungarica, 41, 313-326.

Thierstein, H. R. 1980. Selective dissolution of Late Cretaceous and Earliest Tertiary calcareous nannofossils: Experimental evidence. Cretaceous Research, 2 , $165-176$.

Tomljenović, B. 2000. Map-scale folding and thrust faulting in Eocene flysch sediments (The Bay of Omiš). Vijesti Hrvatskoga geološkog društva, 37, $106-108$

Tunis, G. \& Venturini, S. 1992. Evolution of the southern margin of the Julian Basin with emphasis on the megabeds and turbidites sequence of the southern Julian Prealps (NE Italy). Geologia Croatica, 45, $127-150$.

VARGA, P. 1982. The lower marine member of the Tard Clay: Its age on the foraminiferal evidence of allodapic limestone beds. Földtani Közlöny, 112, 177-184.

VARGA, P. 1985. Turbiditic limestone intercalations of the Buda Marl and Tard Clay. Öslénytani Viták, 31, 93-99.

VAROL, O. 1998. Palaeogene. In: Bown, P. R. (ed.) Calcareous nannofossil biostratigraphy. Chapman and Hall, London, 200-224.
Vlahović, I., TišLJar, J., Velić, I. \& MatičEC, D. 2005. Evolution of the Adriatic carbonate platform Palaeogeography, main events and depositional dynamics. Palaeogeography, Palaeoclimatology, Palaeoecology, 220, 333-360.

VRABEC, M. \& FoDOR, L. 2006. Late Cenozoic tectonics of Slovenia: Structural styles at the northwestern corner of the Adriatic microplate. In: PINTER, N., GRENERCZY, G., Weber, J., Stein, S. \& Medak, D. (eds) The Adria Microplate: GPS Geodesy, Tectonics and Hazards. NATO Science Series IV, 61, Springer, 151-168.

Young, J. R. 1998. Neogene. In: Bown, P. R. (ed.) Calcareous nannofossil biostratigraphy. Chapman and Hall, London, 225-265.

YounG, J. R. \& Bown, P. R. 1997. Cenozoic calcareous nannoplankton classification. Journal of Nannoplankton Research, 19, 36-47.

ŽIVKOVIĆ, S. 2004. Smaller benthic foraminifers from the Eocene clastics from western Croatia: Paleoecology of sedimentary basin. PhD. Thesis, University of Zagreb, Zagreb.

ŽIVković, S. \& BABIĆ, LJ. 2003. Paleoceanographic implications of smaller benthic and planktonic foraminifera from the Eocene Pazin Basin (coastal Dinarides, Croatia). Facies, 49, 49-60.

ZuPANIČ, J. \& BABIĆ, LJ. 1991. Cross-bedded sandstones deposited by tidal currents in the Eocene of the Outer Dinarides (Island of Rab, Croatia). Geološki vjesnik, 44, 235-245. 